UNIVERSITY OF ANTWERP

INSTITUTE OF DEVELOPMENT POLICY AND MANAGEMENT

Dissertation

\title{
The Role of Host Country Factors and Institutional Framework for FDI Spillovers in Ethiopia: The Case of Manufacturing Sector
}

\author{
Eyayu Tesfaye
}

Master of Globalization and Development

Supervisor: Prof. Dr. Marco Sanfilippo

Academic Year 2015-2016

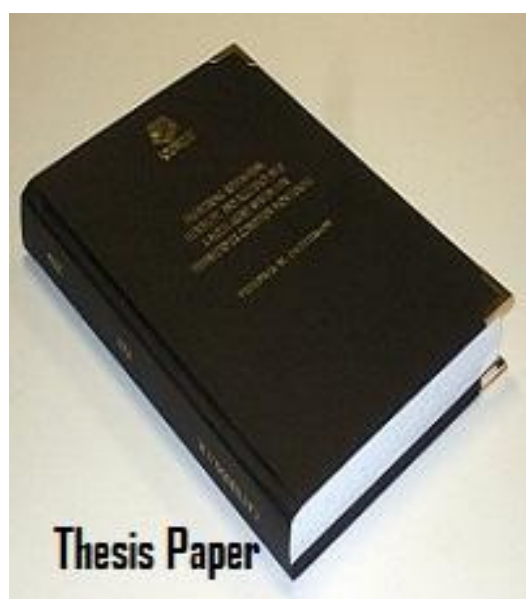




\section{Preface}

This dissertation is submitted in partial fulfillment of the requirements for the award of the Master of Globalization and Development of the Institute of Development Policy and Management (IOB) of the University of Antwerp.

The dissertation focuses on the role of selected macro level factors and institutions in mediating the FDI spillovers in the manufacturing industries of Ethiopia. With the aim of speeding up the country's economic development; government undertakes various policy reforms. Especially, FDI specific policy reforms results in steady inflow of FDI to the country in general and to manufacturing sector in particular. Substantial research has been conducted on macroeconomic economic contribution of FDI inflow to the country. However, productivity gains of domestic firms from technology and knowledge transfer is the most valuable contribution of FDI to long-run economic development of the country. I am interested in assessing the issue due to two reasons: Firstly, as far as our knowledge is concerned, the role of host country factors and institutional framework of the country as mediating factor for FDI spillovers has not been investigated. Secondly, it is very timely and important to assess empirically the spillovers effect of FDI with in manufacturing industries in Ethiopia as the sector is the pillar for industrial development programme of the country.

In my quest to do this study, I have received immeasurable support from various people and I would like to take this opportunity to thank them. Above all, I would like to express my endless gratitude to the Almighty God. I owe my greatest debt to my supervisor, Prof. Dr. Marco Sanfillipo, for his excellent guidance, constructive comments and breakthrough communications.

I would like to thank my families for their all rounded support throughout my work. My sincere thanks must also go to my colleagues Abeba Nigussie, Andualem Goshu, Atlaw Alemu, Henok Arega, Martha Kibru and Mulugeta Ayehu for their invaluable morale and technical support.

Finally, special thanks are reserved to VLIR-UOS Scholarship for their financial support throughout my stay. 


\section{Table of Contents}

Preface

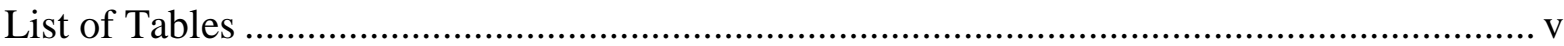

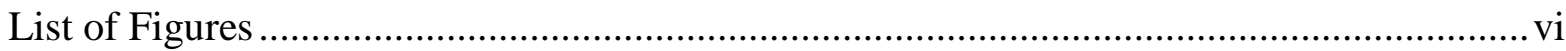

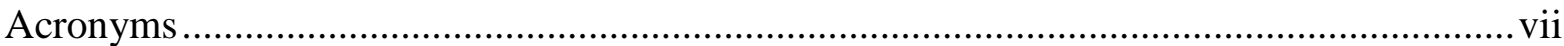

Executive Summary ............................................................................................ vii

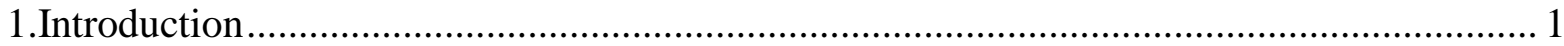

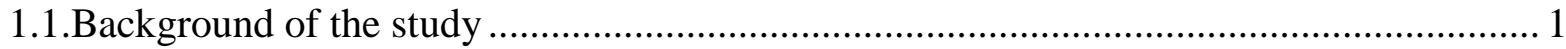

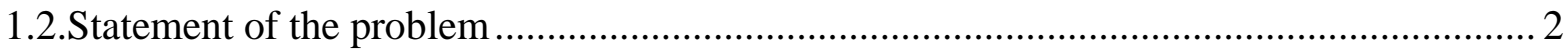

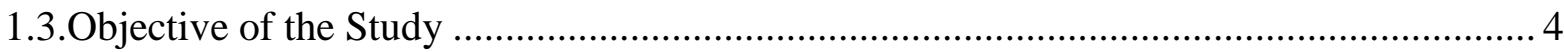

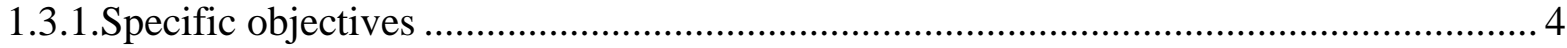

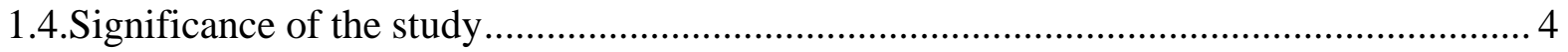

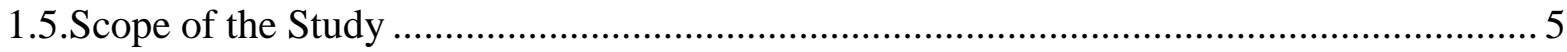

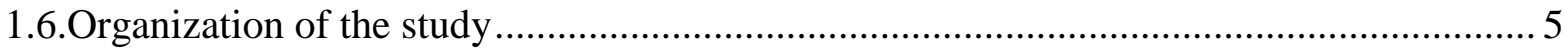

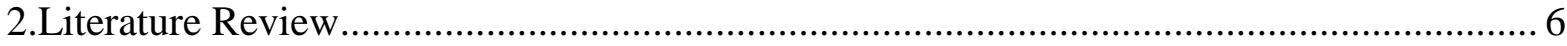

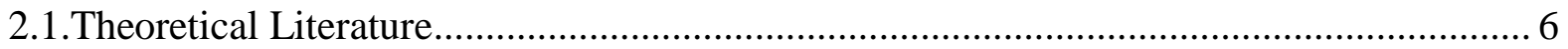

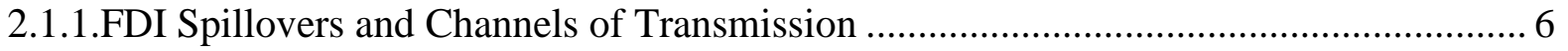

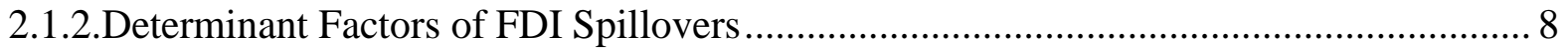

2.1.2.1.Domestic and Foreign Firm Characteristics ……….................................................. 9

2.1.2.2.Host Country Factors and Institutional Framwork: Main Arguments ........................ 10

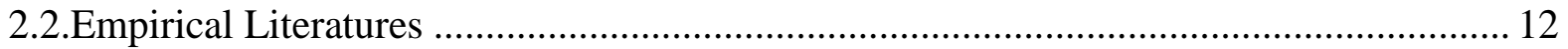

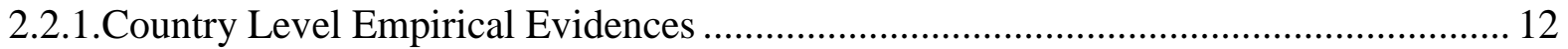

2.2.2.Firm and Industry Level Empirical Evidences .......................................................... 13

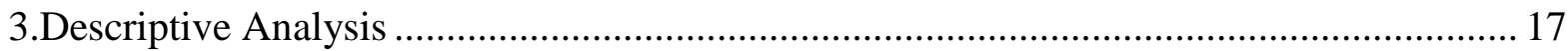

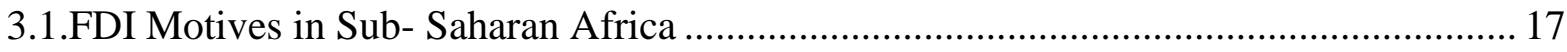

3.2.The Effects of FDI on Domestic Firms in Sub-Saharan Africa........................................ 18

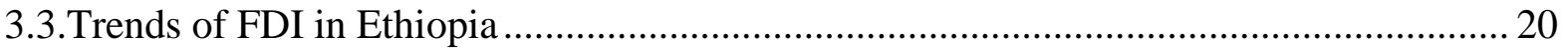

3.4.Ownership, Sectoral and Regional Distribution of FDI in Ethiopia ................................. 21

3.5.Performance of Manufacturing Sector in Ethiopia .............................................................. 23

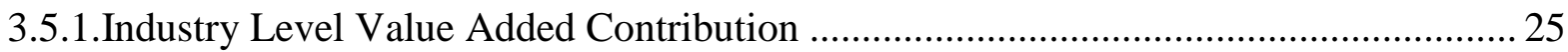

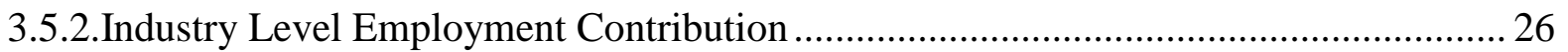

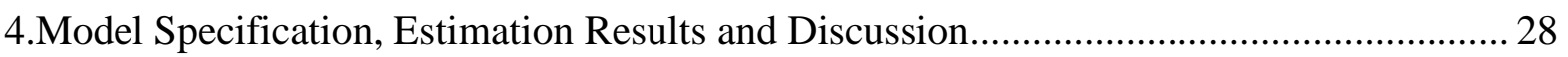

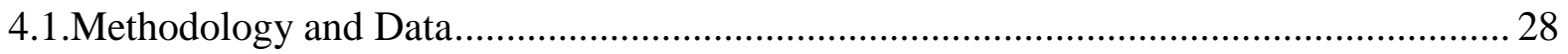

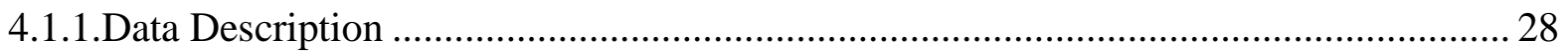




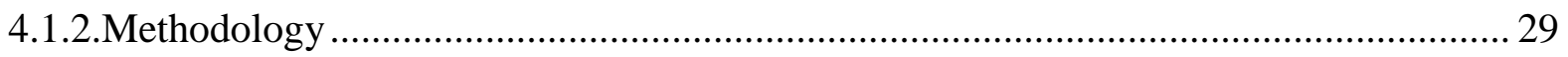

4.2.Model Specification and Definition of Variables .......................................................... 29

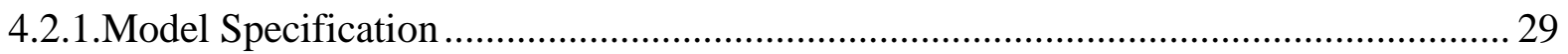

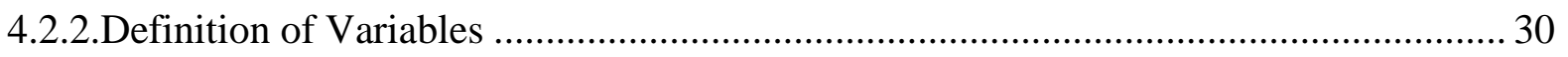

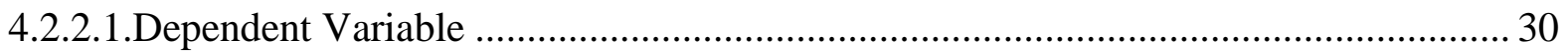

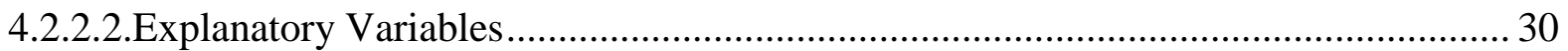

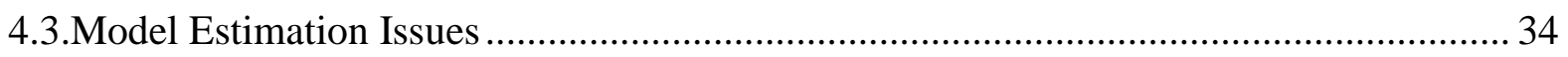

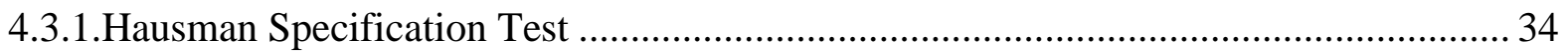

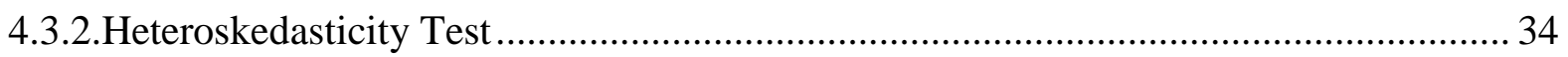

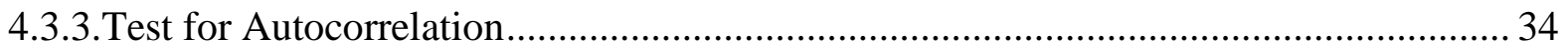

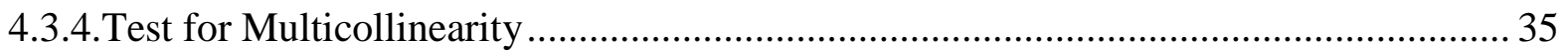

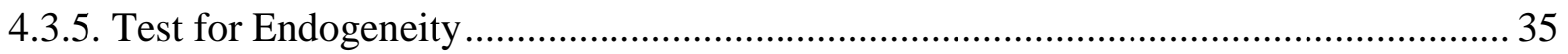

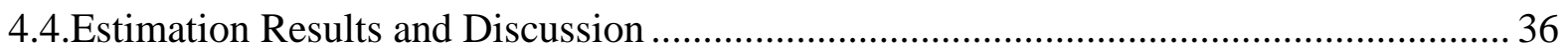

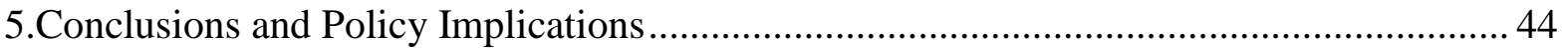

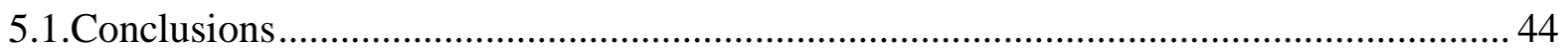

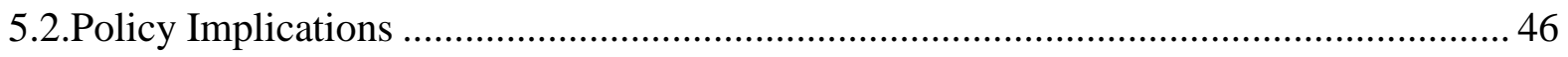

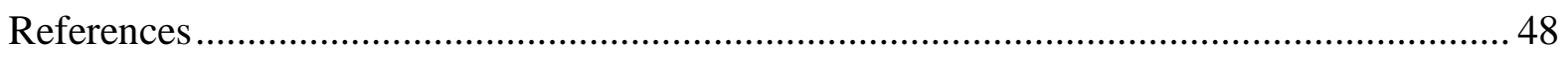

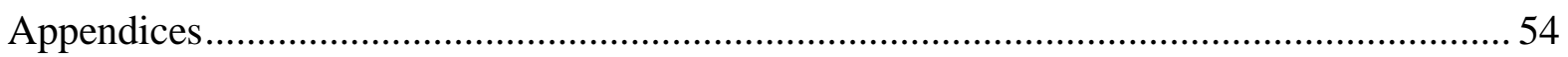




\section{List of Tables}

Table 1: Contribution of Manufacturing Sector to GDP, Export and Import of Ethiopia----25

Table 2: Fixed Effects Estimation for Model 1 and Model 2--------------------------------------37

Table 3: Fixed Effects Estimation for Model 2 and Model 3--------------------------------------39 


\section{List of Figures}

Figure 1: Role of Mediating Factors for FDI Spillovers: A Conceptual Framework-----------8

Figure 2: Share of FDI, Natural Resource and Manufacturing to GDP in SSA--------------- 18

Figure 3: The Net Effects of Inward FDI on Domestic Firms in SSA-------------------------20

Figure 4: Annual FDI Inward Stock in Ethiopia-------------------------------------------------21

Figure 5: Capital of Approved Investment Projects by Source------------------------------------22

Figure 6: Share of Employment by Major Industrial Group--------------------------------------27 


\section{Acronyms}

$\begin{array}{ll}\text { ADI } & \text { Africa Development Indicators } \\ \text { CSA } & \text { Central Statistics Authority } \\ \text { EIA } & \text { Ethiopian Investment Agency } \\ \text { FDI } & \text { Foreign Direct Investment } \\ \text { GDP } & \text { Gross Domestic Product } \\ \text { GTP } & \text { Growth and Transformation Plan } \\ \text { ISIC } & \text { International Standard Industrial Classification } \\ \text { MOFED } & \text { Ministry of Finance and Economic Development } \\ \text { OECD } & \text { Organization for Economic Co-operation and Development } \\ \text { SAP } & \text { Structural Adjustment Programs } \\ \text { SSA } & \text { Sub-Saharan Africa } \\ \text { TFP } & \text { Total Factor Productivity } \\ \text { UNCTAD } & \text { United Nations Conference on Trade and Investment } \\ \text { UNIDO } & \text { United Nations Industrial Development Organization } \\ \text { WB } & \text { World Bank } \\ \text { WDI } & \text { World Development Indicators }\end{array}$




\section{Executive Summary}

In relation to the rapid economic growth and various investment policy reforms; the number and types of FDI inflows to Ethiopia has been increasing. These steady inflows of FDI deliver important contributions to employment, foreign exchange and revenue generation of the country. FDI also affects the domestic economy indirectly through various channels one of which is productivity improvement of domestic firms resulting from technology and knowledge spillovers. The dynamic gains through spillovers from multinationals to local firms are the most valuable contribution of FDI to long-run growth and development of the country.

However, the spillovers effect of FDI does not accrue automatically with the presence of foreign firms. There are various mediating factors affecting the knowledge and technology transfer from foreign to domestic firms one of which is host country factors and institutional framework. The net impact of FDI on domestic firms largely depends on the host country factors and institutional framework where the other mediating factors are situated. As far as our knowledge is concerned, none of the previous studies assess the role of host country factors and institutions as a mediating factor in analyzing the effect of FDI spillovers in Ethiopia in general and with in the manufacturing sector in particular.

This study is, therefore, aimed at assessing the role of host country factors and institutions in mediating the intra-industry productivity spillovers in the manufacturing industry. Specifically, the paper addresses the productivity effect of interaction of FDI spillovers variables with labor freedom index, investment freedom index as well as trade openness and financial efficiency index of the country. Moreover, the study analyses the productivity spillovers effect through labor mobility channels and other channels of horizontal transfer separately.

In this study, we use firm-level survey data on large and medium scale manufacturing industries collected by the Central Statistics Authority (CSA) of Ethiopia covering the period 2003 to 2010. The number of firms per year varies from a low of 730 in 2004 to high of 1863 in 2009.After deleting observations with zero employment, output, and sales value; the data is organized as unbalanced panel consisting of 11131 observations with in 52 manufacturing industry categories based on ISIC Revision 4.1 classification. Regarding ownership, we 
consider firms with total share of foreign ownership of 10 percent and above as FDI based on UNCTAD and OECD classification. The firm-level data is combined with country-level data to control for effect host country factors and institutional framework. The country level data is obtained from ADI, WDI and Heritage foundation databases. Moreover, the data obtained from Ethiopia Investment Agency is also used for descriptive analysis.

We use both descriptive and econometrics as a method of analysis to address the above objectives. The descriptive analysis shows that employment and gross capital formation contribution of FDI has been increasing in the country. Sector wise, manufacturing sector takes largest share during the period under consideration. The largest share of manufacturing sector is attributed to special tax and non tax related incentive schemes to investors engaged in the sector. Some of the incentives include 100 percent exemption from custom duties, domestic loan up to 70 percent of the investment capital, and low land lease rate among others. Industry wise, labor intensive manufacturing industries contribute more than 90 percent of employment and value added in the sector. However, the sectors' contribution to value added and export is lower relative to agriculture and service sectors of the country as well as the Sub-Saharan Africa average.

For the econometric analysis, panel data econometrics with fixed effects estimation technique is used as a method of analysis. After addressing all the estimation issues, we estimate the baseline model containing only the interaction terms as an explanatory variable and the extended model incorporating observable and unobservable control variables. The observable control variables, industry fixed effects and firm fixed effects are included in the model after checking their respective significance. We incorporate these variables in our estimation to be more confident in isolating the spillovers effect of FDI on productivity of domestic firms.

The estimation result revealed that the intra-industry spillovers effect of FDI on productivity of domestic firms is positive except through the labor mobility channel which will not be reversed even in one year. The highly flexible labor market and wage difference facilitates the employee's turnover from domestic to foreign firms. In contrast, the estimation result suggests that the degree of openness, human capital stock and financial sector efficiency positively and significantly mediates the productivity effect from FDI. Concerning the control variables included in the model, capital intensity and age positively and significantly 
affects domestic firms' productivity. The effect of sector level concentration on firm's productivity is also positive but not significant.

Our result clearly shows that the country's human capital development as well as trade openness and financial development plays a positive role in mediating knowledge and technology transfer between multinationals and domestic firms. However, the country's highly flexible labor market regulation facilitates the labor mobility from domestic to foreign firms which adversely affects productivity of domestic firms.

Overall these findings suggest that apart from targeting to increase the volume of FDI; integrating spillovers as a wider industrial development policy is crucial so as to benefit more from dynamic gains from FDI. Specifically, formulating minimum wage legislation policy and supporting research and training programmes of domestic firms enables to maintain and attract skilled workers and benefit form spillovers. Moreover, further liberalization of financial sector reduce the cost of borrowing and the risk of investment to imitate technology. Similarly, further liberalization of trade increases the domestic firm's participation in global value chains and their respective productivity gains from spillovers. Furthermore, government should promote FDI-local industry linkages through creating regional industrial parks, implementing minimum local content requirments as well as facilitating joint research and training programmes..Finally, creating reliable regulatory starndards, encouraging entry of new firms, and providing adequate infrastructure can play a constructive role in facilitating spillovers from foreign to domestic firms. 


\section{Introduction}

\subsection{Background of the study}

Economic growth of Sub-Saharan African countries shows an increasing trend since the period 1980s. The increase in integration of Sub-Saharan Africa with global economies through gradual liberalization results in a soaring economic growth. In relation to this, the inflow of FDI to the region shows an increasing trend. The steady inflow of FDI contributes not only to bridge employment and foreign exchange gaps but also creates networking and production sharing opportunities to local producers in Sub-Saharan Africa (UNIDO, 2014).

Ethiopian economy is one of the fastest growing economies in Sub-Saharan Africa. The country has been experiencing economic growth of 10.6 percent per year for the last decade which is over and above the regional average of 5.2 percent (WB, 2012). Accordingly, agriculture accounts 42.7 percent of the GDP, industry accounts for 12.3 percent of the GDP and service sector accounts for 45 percent of the GDP of the country (OECD, 2014). The share of the industrial sector to GDP of the country is less than the Sub-Saharan Africa average of 28 percent (Melaku, 2013). Moreover, the contribution of large and medium scale manufacturing industries to GDP of the country remains very small accounting for 3 percent (MOFED, 2014).

As presented in the five year the Growth and Transformation Plan (GTP) of the country; the government is aimed at transforming the economy by increasing the share of manufacturing sector to 14.9 percent through expanded foreign direct investment (MOFED, 2014). There is also considerable gap between saving and investment of the country which reinforces the need for FDI in the development process of the country (Demeke et al., 2012; Ermias, 2013; Henok, 2014). Recently, FDI becomes an integral part of development policy of the country and special incentive schemes such as providing tax holiday and duty exemption are designed to stimulate FDI inflows to the country (MOFED, 2014).

In relation to the rapid economic growth and investment policy reforms; the number and type of FDI inflow to the country has been increasing (Demeke et al., 2012). The government and policy makers gave considerable attention to attract more foreign direct investment as it affects the economy directly and indirectly. Most of the empirical studies on the direct contribution of FDI to economic growth and its major determinants shows consistent 
outcome (Henok, 2014; Demeke et al., 2012). FDI also affects the domestic economy indirectly through various channels one of which is productivity improvement of domestic firms resulting from technology and knowledge spillovers (Costa da Massingue, 2012; Farole and Winkler, 2012).

Depending on the direction of technology and knowledge diffusion; FDI spillovers can be either intra-industry or inter-industry. The presence of multinationals within a given industry affects the productivity of the local firms either positively or negatively through competition or labor turnover channels which, in turn, depend on the other national characteristics and institutional framework. Whether the intra-industry spillovers effect is positive or negative and how the interaction of foreign presence with macro factors affects the magnitude of FDI spillovers requires further empirical investigation as the research outcomes shows inconsistent results.

\subsection{Statement of the problem}

FDI deliver important contributions to employment, foreign exchange and revenue generations of the country. It also enhances productivity of local firms through knowledge and technology transfer (Asiedu, 2005).The dynamic gains through spillovers from multinationals to local firms are the most valuable contribution of FDI to long run-growth and development of the country.

Despite the prediction of economic literatures that knowledge and technology spillovers from FDI enhances the productivity of domestic firms; empirical investigations shows mixed results (Havranek and Irsova, 2011; Jude, 2013; Lipsey and Sjoholm, 2005). Some studies found that the existence of foreign firms with in the same industry enhances the productivity of domestic firms (Merlevede and Schoors, 2007; Nicolini and Resmini, 2010). Others revealed that the presence of foreign firms adversely affects the productivity of local firms operating within same industry (Farole and Winkler, 2012; Javorcik, 2004). Some other studies found that the intra-industry productivity effect of FDI is not significant (Girma, 2005). All of these studies in common overlook the role of mediating factors in determining the extent of FDI spillovers in their respective analysis.

According to Costa da Massingue (2012) and Farole et al (2014) the spillovers effect of FDI do not accrue automatically with the presence of multinationals. The characteristics of foreign 
firms, which shapes spillover potential; domestic firms capacity which shapes absorptive capacity to internalize the spillovers; and host country factors and institutions determine the magnitude of FDI spillovers.

The interaction of intra-industry FDI spillovers with the host country factors and institutional framework affects productivity of domestic firms (Jude, 2013). According to Boly et al. (2013) the net impact of FDI on domestic firms largely depends on the host country factors and institutions where the other mediating factors are situated. In relation to this, national income, government's spending on research and development, trade openness, labor freedom, financial freedom and property right matters most for FDI spillovers considering heterogeneity of domestic firms (Farole et al., 2014). Empirical studies on the role of host country factors and institutions as a mediating factor in determining the extent of FDI spillovers also shows mixed results (Farole and Winkler,2012).

Some empirical studies examined the horizontal and vertical spillover effect of FDI at industry and firm level in Ethiopia. Abeba (2014) uses panel dataset and extensive econometric analysis to assess the backward, forward and horizontal spillovers effect of FDI in the manufacturing firms in Ethiopia. She found that FDI in the manufacturing industry has a negative forward spillovers effect and a positive backward spillovers effect on the productivity of domestic manufacturing industries. However, the horizontal spillovers effect is indeterminate. Similarly, Ermias (2013), by using firm level cross sectional data, analyze the spillovers effect of FDI inflow to the manufacturing sector on the productivity of domestic manufacturing firms in Ethiopia. He revealed that there is a positive intra-industry spillovers effect and the magnitude of the effect mainly depends on geographical proximity, size, age and labor quality of domestic firms.

As far as our knowledge is concerned, none of the previous studies include the host country factors and institutions role as a mediating factor in analyzing FDI spillovers in Ethiopia in general and with in the manufacturing sector in particular. This study, therefore, focuses on the horizontal spillover effect of FDI in the manufacturing industries in Ethiopia and the role of host country factors and institutions in shaping the magnitude of the horizontal spillovers. 


\subsection{Objective of the Study}

The main objective of this study is analyzing the horizontal spillovers effect of FDI and its interaction with host country factors and institutional framework on productivity of domestic manufacturing firms.

\subsubsection{Specific objectives}

Assessing the effect of foreign firm presence on productivity of domestic manufacturing firms

Analyzing labor mobility effect of foreign firm presence within the industry

\subsection{Significance of the study}

FDI inflow to the manufacturing sector shows an increasing trend in the country in relation to government provision of different incentives for foreign investors. However, the contribution of the sector to GDP, employment and foreign exchange earnings still lags behind the agriculture and service sector. One of the objectives of attracting foreign investment is also enhancing the competitiveness and productivity of domestic industries. Reliable empirical evidence on the horizontal spillovers effect of FDI is required to assess the actual effect of presence of multinationals on local firms within the sector and take policy measures accordingly. Therefore, empirically investigating the spillovers effects of FDI on manufacturing industries in Ethiopia is crucial as the sector is the pillar for the industrial development of the country and prioritized by the government. Moreover, analysing the role of trade policy, financial freedom, human capital development and institutional quality in determining the magnitude of intra-industry spillovers is important so as to evaluate the contribution of macro policies on the sector level performance in the country. Finally, the paper will shed light to further research on the spillovers effect of FDI inflow at the industry as well as firm level in other sectors in Ethiopia. 


\subsection{Scope of the Study}

This paper focuses only on the horizontal spillovers effect of FDI on domestic firms operating in the manufacturing sector and how mediating factors affects the magnitude of FDI spillovers. Sector wise, manufacturing industries in Ethiopia are used as a unit of analysis. As per the International Standard Industrial Classification (ISIC) of all economic activities Revision 4.1; the industries from 1511 to 3610 which are classified under manufacturing industries are included in this study. The unbalanced panel data set from Central Statistics Authority (CSA) of Ethiopia for the period 2003 to 2010 and selected host country factors and institutional framework variables from Heritage foundation and WDI dataset are used.

\subsection{Organization of the study}

The structure of the paper is organized as follows: Section 2 presents theoretical literature on FDI spillovers, main arguments on the role of mediating factors and country as well as firm and industry level empirical evidences. Section 3 contains descriptive analysis on motives and the effect of FDI on domestic firms in Sub-Saharan Africa in general and in Ethiopia in particular. In this section, we also present analysis on trends of FDI, sectoral and regional distribution, and performance of manufacturing industries in Ethiopia. Section 4 is devoted to methodology, data description and econometric analysis. The final section of the paper highlights concluding remarks and policy implications. 


\section{Literature Review}

\subsection{Theoretical Literature}

\subsubsection{FDI Spillovers and Channels of Transmission}

Domestic firms benefit from firm specific endowment of multinationals such as superior technology, management techniques, and marketing strategies. All the knowledge and technology from the multinationals may not be fully internalized, hence, spills over to domestic firms (Crespo and Fountoura, 2007; Javorcik, 2004). The technology and knowledge spillovers, therefore, may enhance productivity of local firms (Javorcik, 2004).

Depending on the direction of diffusion; spillovers effect of FDI on domestic firms can be either intra-industry or inter-industry which can occur through backward and forward linkages of multinationals with domestic firms (Ermias, 2013; Jude, 2013). The horizontal spillovers can take place when the presence of multinationals influences the productivity of the domestic firms operating within the same industry (Crespo and Fountoura, 2007). Moreover, intra-industry FDI spillovers can occur through demonstration and imitation of new technologies, labour turnover and competition with multinationals (Crespo and Fountoura, 2007; Farole et al., 2014). According to Jude (2013) the positive effect of technology transfer due to the presence of multinationals is difficult to separate from its negative effect through competition.

The spillovers through imitation will be more effective when firms produce similar products. If multinationals produce output for international market and domestic firms produce products for local market using different technology spillovers through imitation will decrease (Javorcik, 2004b as cited in Crespo and Fountoura, 2007).Similarly, knowledge spillovers can occur when multinationals provide technical assistance to input supplying firms (Farole et al.,2014). Exposition to foreign firms marketing strategies, production process and distribution networks benefit the local firms in the form of knowledge diffusion. According to Boly et al (2013) and Farole et al (2014) the demonstration effect on domestic firms highly depends on its absorptive capacity, learning and innovation infrastructure, proximity and interaction with foreign firms and FDI motive among others.

Labor turnover and intense competition in host country markets are also alternative transmission channels of horizontal FDI spillovers to the local firms. The labor mobility 
effect of FDI spillovers might be either negative or positive depending on the capacity of domestic firms to attract workers working in multinationals (Farole and Winkler,2012). Spillovers through labor turnover depend on the ability of domestic firm to offer competitive wage which, in turn, depends on other mediating factors. The investment of multinationals may result in a negative spillover in the short-run through shifting skilled workers from local firms by offering higher wages. In the long term, however, skill and knowledge of workers may not be completely internalized by multinationals hence domestic firms will benefit through labor turnover (Crespo and Fountoura, 2007; Farole et al., 2014; Hoekman and Javorcik, 2006).

Analogously, the existence of foreign firms in the host economy will have a competition effect in the factor as well as the product market. The presence of multinationals in local economy may increase the level of competition which forces the domestic firms to adopt more innovative technology and utilize the available resources efficiently. On the other hand, stiff competition from multinationals may have crowding out effect on domestic firms by reducing the market shares (Havranek and Irsova, 2011).

According to (Crespo and Fontoura, 2007; Farole and Winkler, 2012; Javorcik, 2008) in the short-run local firms may lose market and output share but in the long-run the productivity and reliability of local producers might improve to cope up with foreign competitors. The domestic firms research and development capacity, workers skill, firm size, technological gap and host country's policy environment determines the domestic firms capacity to compete and internalize FDI spillovers,

On the other side of the spectrum, the vertical spillovers effect of FDI can be either backward through increasing demand for factor inputs from local suppliers or forward by selling part of the output to domestic firms operating in other sectors (Javorcik, 2004). Domestic firms buying inputs from similar suppliers with multinationals may be adversely affected by high price and demand for standardized inputs (Jude, 2013). The vertical spillovers through supply chains depend on the domestic and foreign firm characteristics(Farole et al., 2014).Moreover, the availability and quality effect depends on the technological intensity and productivity of multinationals and domestic firms. Larger, newly established and more productive firms are more likely to benefit from interaction with foreign firms (Boly et al., 2013). 


\subsubsection{Determinant Factors of FDI Spillovers}

The existence and magnitude of FDI spillovers to domestic firms depends on various firm and macro level mediating factors (Crespo and Fontoura, 2007). The occurrence of FDI spillover depends on the presence of interaction, labor market conditions, availability and quality of institutions, trade orientation, ownership structure and size of firms among others (Gachino, 2012). According to (Farole et al.,2014) mediating factors which determine the extent of FDI spillovers can be classified as absorptive capacity of domestic firms, foreign firms spillovers potential, host country characteristics and institutional framework.

The host country characteristics and institutional framework, in turn, influences the FDI spillovers potential of foreign firms, absorptive capacity of domestic firms and transmission channels (Crespo and Fontoura, 2007; Farole and Winkler, 2012). The focus of this study is the role of host country factors and institutional framework on FDI spillovers in manufacturing industries in Ethiopia. Therefore, much section is devoted to the main arguments on the role of host country factors and institutional framework on FDI spillovers based on the conceptual framework of Farole et al (2014).

\section{Figure1: Role of Mediating Factors for FDI Spillovers: A Conceptual Framework}

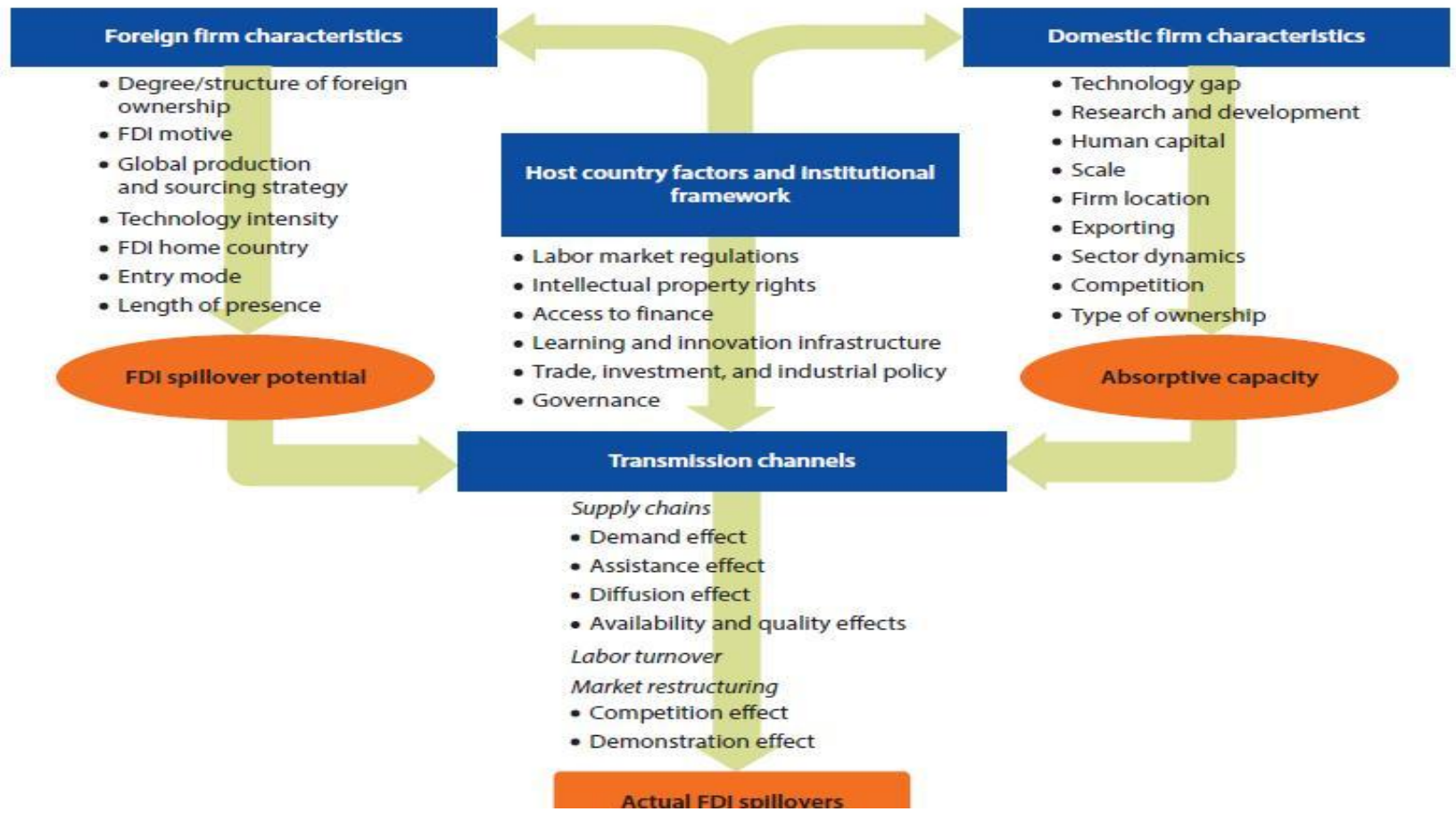

Source: Making FDI Work for Sub-Saharan Africa Farole et al (2014) 


\subsubsection{Domestic and Foreign Firm Characteristics}

As shown in the above conceptual framework, both the domestic and foreign firm characteristics influence the extent of FDI spillovers from multinationals to domestic firms. Technological gap between domestic and foreign firms is one of the major mediating factors which determine the extent of FDI spillovers. Some argue that FDI spillovers effect is an increasing function of technological gap between the domestic and foreign firms. The more the domestic firms lag behind multinationals; the more benefit firms can get due to "catching up' effect (Jordaan, 2011). Others argue that the smaller the technological gap; the higher will be the chance to absorb spillovers by the local firms (Amighini and Sanfilippo, 2014; Blalock and Gertler, 2009).

The level of competitive pressure from multinationals also determines the extent of FDI spillovers. The higher the competitive pressure from the already existed local firms at the sectoral level; the lower will be the pressure from multinationals and hence lower benefit from FDI spillovers (Farole et al., 2014). Similarly, the degree of foreign ownership influences the spillovers absorbing potential of local firms. Some studies argue that larger degree of domestic ownership will make technological transfer more likely by creating intersectoral linkages with the local economy (Crespo and Fontoura, 2007). Some others argue that technological transfer will increase with the increase in foreign ownership which makes spillovers easier (Farole and Winkler, 2012).

Another factor influencing FDI spillovers potential is the motive of FDI undertaking by foreign multinationals. Resource seeking FDI has limited potential for spillovers due to its high capital and technology intensity while asset seeking FDI has relatively higher spillover potential due to closer relationship with local supplier, workers and customers (Farole et al., 2014). Finally, entry mode also determines the extent of spillover. Greenfield investment implements leading technology and do have higher spillover potential than merger and acquisition which adopts host countries technology (Crespo and Fontoura, 2007). 


\subsubsection{Host Country Factors and Institutional Framwork: Main Arguments}

As shown in the above conceptual framework, labor market regulation, trade, investment and industrial policy, access to finance, intellectual property rights, learning and innovation infrastructure determine the magnitude of actual FDI spillovers to domestic firms. The interaction of FDI spillovers variable with these macro level factors determines the spillovers effect of FDI on the productivity of domestic firms.

Labor market regulation determines the type and the amount of FDI, willingness to invest in job training and workers skill which, in turn, determines domestic firms' absorptive capacity.

It also affects the transmission channel through the nature and frequency of labor turnover. Highly rigid labor market reduces the possibility of labor turnover and highly flexible labor market may result in frequent turnover which reduces chance for acquiring spillovers (Farole and Winkler, 2012; Hale and Long, 2011).

Some argue that strong intellectual property rights increase the inflow of FDI and possibility of spillovers. Others argue that strong intellectual property rights is a barrier for domestic firms to imitate and may lead to less positive horizontal spillovers (Crespo and Fontoura, 2007; Smeets, 2011). Multinationals use protection of intellectual property rights to prevent technological spillovers; if domestic firms are competing with in the same sector. Loose protection of intellectual property rights makes multinationals to prefer distribution and marketing activity to local production which reduces the occurrence of spillovers (Javorcik, 2004).

The role of access to finance as mediating factor for FDI spillovers is also controversial. Some argue that well developed financial system favors the existence of FDI spillovers as it reduces the risk of investment to imitate technology and skill development of workers (Agarwal et al., 2011; Hermes and Lensink, 2003). Better access to finance enhances the absorptive capacity of domestic firms and their benefit from technological spillovers. Moreover, horizontal spillovers will be lower in countries with lower financial development (Alfaro et al., 2004). Others argue that when multinationals borrow from local institutions; financial constraint for local firms will be high and their absorptive capacity and spillovers potential will be low (Farole and Winkler, 2012; Havranek and Isrova, 2011). 
The other important mediating factors determining FDI spillovers are learning and innovation infrastructure, trade, investment and industrial policy. Trade policy is identified as most important catalyst for FDI spillovers. Trade openness can increase the productivity spillovers from FDI; while trade barrier encourages investment in less productive import substituting industries. This is called the "Bhagwati" Hypothesis" (Lesher and Miroudot, 2008; Havranek and Irsova, 2011). Bhagwati (1978) hypothesized that a country with an export-oriented trade policy will attract a greater volume of FDI and use the resource efficiently relative to the one that adopts import-substitution strategy. Therefore, FDI spillovers are likely to be positive in a country that adopts export promotion policy than import substitution regime.

Some other studies argue that inward-oriented trade policies make multinationals to focus on local markets and use new technologies which results in high FDI spillover through learning and demonstration effect (Crespo and Fontoura,2007; Kokko et al, 2001). Human capital is also a crucial mediating factor in enhancing the productivity of local firms. According to Rao and Tesfahunegn (2015) adopting and sustaining modern technology and improving productivity of firms requires skilled worker.

Exporting is the other channel through which domestic firms can benefit from existence of multinationals (Greenway et al, 2004). There is no clear evidence whether exporting improves or lowers the extent of positive FDI spillovers (Falore et al, 2014). On one hand, by adopting export process of foreign firms, domestic firms will reduce entry cost to international market and enhance their respective productive efficiency (Crespo and Fountoura, 2007). On the other hand, if the local firm is net exporter the competitive pressure from foreign firms will be low, provided that multinationals does not enter in to the export market, which lowers the extent positive FDI spillovers (Farole and Winkler, 2012).

Analogously, investment policy and promotion also plays a significant role in mediating spillovers. Investment promotion agency arranges export processing zones which can affect the extent of FDI spillovers. Some argue that arranging special economic zones will limit the spillover potential if the exporters use larger proportion of imported inputs and if the legal structure inhibits integration of multinationals with local producers (Abraham et al, 2010). Another host country factor affecting extent of FDI spillovers is industrial policy of the country. Accordingly, policies supporting micro and small enterprises and the local content 
requirement rule reduces high technological gap between the domestic and foreign firms and enhances the extent of FDI spillovers (Farole and Winkler, 2012).

Finally, the host country institutional environment can shape the extent of FDI spillovers. Corruption and poor contract enforcement leads foreign firms to internalize production or to import from intermediary reduces interaction with local suppliers (Perez-Vilar and Seric, 2014). Some also argue that institutional distance matters more than the institutional quality for linkage between multinationals and local firms (Cuevero-Cazurra and Genc, 2008). The relationship between the country's per capita income and FDI spillovers is ambiguous.

Spillovers through labor mobility to domestic firms is lower in low income countries as there is high wage differential between multinationals and domestic firms (Lipsey et al., 2004).

\subsection{Empirical Literatures}

\subsubsection{Country Level Empirical Evidences}

In relation to the above contrasting theoretical arguments, in this section, we try to assess range of empirical literatures on the role of host country factors and institutional framework as mediating factors in determining the extent of FDI spillovers at the country level. Sisay (2008) analyze the nexus between FDI and Total Factor Productivity in Sub-Saharan Africa using dynamic panel model. He found that FDI enhances TFP growth in countries having well developed financial sector. He also revealed that the effect of FDI on TFP growth is negative in countries adopting open trade policy. The sectoral share of Agriculture, industry and service sectors for the GDP of the country also determines the spillovers effect of FDI. A study by Sisay (2008) also shows that Sub-Saharan Africa countries having larger share of agriculture in their GDP experience lower TFP growth caused by FDI.

Analogously, institutional homogeneity and institutional distance determines sign and magnitude of FDI spillovers. Perez-Vilar and Seric (2014) assess the role of institutional distance on FDI spillovers by using cross section of manufacturing firms in Sub-Saharan Africa and found that institutional homogeneity between the host and source country and cultural proximity results in positive spillovers. The study also revealed that institutional distance matters for positive spillovers more for North-South FDI than South-South. (Gorg et al, 2014) examine how the horizontal productivity effect differs based on the heterogeneity of FDI in Sub-Saharan Africa by using panel data econometrics. He revealed that productivity spillovers are greater in South-South FDI than North-South FDI. Moreover, horizontal 
productivity spillover from FDI depends on the domestic firms' absorptive capacity and income level of host country.

Farole and Winkler (2012) analyze role of mediating factors for FDI spillovers in cross section of 25,000 firms in 78 low and middle income countries by taking in to account the firms' productivity difference. They found that open trade policy, high spending on education and well developed financial markets positively mediates FDI spillovers to low productivity firms in these countries.

\subsubsection{Firm and Industry Level Empirical Evidences}

As spillovers effect is not directly measurable, most of the empirical studies use the share of foreign firm output out of the total industry level output as proxy for FDI spillovers. In most firm and industry level studies, value added per employee is used to measure labor productivity in analyzing the spillover effect of foreign firm presence on productivity of domestic firms as well as industries (Crespo and Fontoura, 2007).

Lenaerts and Merlevede (2012), using Romanian firm level panel dataset and input-output table, analyse the vertical and horizontal spillovers effect of the FDI by considering the degree of industrial aggregation. The study confirms that horizontal spillovers present at higher level of aggregation whereas vertical spillovers decline with the increase in aggregation. Similarly, Merlevede and Schoors (2007) assess the spillovers effect of FDI on sample of Romanian firms and found positive horizontal effect on domestic firms through labour turnover from multinationals. However, its effect on local suppliers is negative. Nicolini and Resimini (2010) conducted similar study by incorporating firms in two more countries and analyse the role of technological gap in FDI spillovers and found that larger technological gap is a barrier for domestic firms to take advantage of positive spillovers effect.

Stancik (2009), using firm level data for Czech Republic, assess the horizontal and vertical spillovers effect of takeovers and Greenfield FDI on sales growth rate of domestic firms. He found that there is positive horizontal spillovers effect from foreign takeovers and negative horizontal spillovers effect from Greenfield FDI. The study also revealed that sales growth effect of FDI is negative in the upstream sectors. According to Amendolagine et al (2013) 
Greenfield investment with natural resource and market seeking motive of investors results in weak linkage and limits the FDI spillovers to domestic firms in SSA.

Zhou (2014) conducted a study on analysing the effect of FDI on the technical efficiency of domestic manufacturing firms in five African countries using stochastic frontier analysis for the period 1991 to 2003 . He reiterated that FDI presence improves the technical efficiency of large export-oriented manufacturing firms and lowers the technical efficiency of older domestic firms as compared to the new once.

Industry level empirical analysis is conducted by Abeba (2014) on the spillovers effect of FDI on the domestic manufacturing industries in Ethiopia by using panel dataset for the year 2004-2010. She found that foreign firm presence in the manufacturing sector do have positive backward spillovers and negative forward spillovers effect on the productivity of local manufacturing firms. Ermias (2013), using cross sectional data on Ethiopia for the period 2009, conducted a similar study and revealed that foreign firm presence in the manufacturing sector results in positive intra-industry spillovers effect but the magnitude depends on geographical proximity, size and age of firms among others.

Ofosu and Waldkirch (2008) assess the effect of foreign firm presence on productivity and wage paid by manufacturing industries in Ghana using firm level panel data considering differences in degree of ownership. They found that the presence of foreign firms adversely affects the productivity of domestically owned firms but positively affects most of foreign owned multinationals in the domestic economy. Moreover, there is no evidence on the effect of foreign firm presence on wage paid by domestic manufacturing firms. Gorg and Strobl (2005) also use the panel data set to analyse the productivity effect of FDI on domestic firms through labour mobility as channel of transmission in Ghana. The study revealed that mobility of experienced workers to domestic firms enhances productivity.

The net horizontal spillovers effect of FDI depends on the magnitude of the competition and labour mobility effect. The increase in productivity arising from labor turnover may be offset by the adverse competition effect. (Jude, 2013) assess horizontal spillovers effect of FDI on the Romanian firms and found that the effect of technological spillovers occurred through labor mobility positively affects productivity of domestic firms. 
Frederick and Staritz (2012) empirically assess the spillovers effect of FDI in three leading apparel exporting countries in SSA. The study reiterated that despite FDI boom to the sector, there is no spillover effect on the local firms. This is attributed to external control of sourcing, reliance on foreigner workers for management as well as technical positions. Moreover, barriers in local business climate and use of ineffective policy to support small and microenterprises also limits the spillover effect of FDI in the sector

The interaction of mediating factors with FDI spillovers variable determines the productivity effect of FDI on domestic firms. (Jude, 2013), with data for Romanian firms, conducted a study on the role of mediating factors on FDI spillovers. The study revealed that the interaction of spending on research and development and larger technological gap with the horizontal spillovers variables positively affects total factor productivity of domestic firms. Similarly, the backward spillovers variable and its interaction with the technological gap also positively affect the total factor productivity of domestic firms.

Boly et al (2013) conducted a firm level analysis on the role of institutional environment as a mediating factor for sample of firms in 19 Sub-Saharan Africa countries. They reiterated that countries with weak institutional environment such as wide spread corruption experience positive net effect from FDI spillovers. The study also found that firms with exporter status benefit from interaction with foreign firms

Similarly, Kokko et al (2001) assess the impact of the interaction FDI spillovers variable with trade policy on the productivity of Uruguayan manufacturing sector by taking 1973 as a period of demarcation for policy change. The study reiterated that FDI spillovers effect is positive during the inward oriented trade policy regime before 1973 and negative during open trade policy regime. Kohpaiboom (2009), using panel data econometric analysis, assess the spillovers effect of FDI on the productivity of manufacturing firms in Thailand considering trade policy as mediating factor. He found that trade liberalization facilitates positive horizontal spillover effect of FDI on domestic firms. The outcome is in line with the “Bhagwati' hypothesis. Similarly, Temenggung(2007) assess the effect of economic policy change on the horizontal spillovers effect of FDI on Indonesia manufacturing firms and found that FDI spillovers becomes positive after economic liberalization and it was negative before the economic liberalization. 
The exporting status of the firm also determines the extent of FDI spillovers. Some studies argue that domestic firms engaged in exporting gain more from FDI relative to non exporters. Jordaan(2011) assess the spillover effect of FDI on domestic firms in Mexico and reiterated that intra-sector spillover from FDI benefit more the exporting firms as compared to nonexporters.

The sector or firm level spillovers effect of FDI is also determined by the labor market regulation. According to Hale and Long (2011) presence of foreign firms due to their competition effect in China creates upward pressure on the wage paid by domestic firms for skilled labors. This results in shift of low quality skilled workers to wage constrained domestic firms which, in turn, reduces the absorptive capacity of domestic firms. The intellectual property right also determines the type of FDI and the extent of spillovers to domestic firms. Javorcik (2004b) assess the role of intellectual property rights on FDI spillovers by taking sample of firms form central and Eastern Europe. He found that the magnitude of FDI spillovers is high in high tech producers with strong property right and it is lower in sector with weaker property rights.

Analogously, access to finance and spending on learning and innovative infrastructure affects the FDI spillover from multinationals to domestic firms. A study by Agrawal et al (2011) revealed that FDI spillover are lower and even negative for manufacturing firms in China having credit constraint. Tytell and Yudaeva (2007) analyses the firm level effect of availability of learning and innovative infrastructure in Romania and found that FDI spillovers effect on productivity of manufacturing firms is low in regions with lower share of spending on education. 


\section{Descriptive Analysis}

\subsection{FDI Motives in Sub-Saharan Africa}

The motives of undertaking FDI might be resource-seeking, efficiency-seeking or marketseeking which determines the extent of spillovers. According to Farole et al (2014) the extent of spillovers is limited in the case of resource-seeking FDI as the multinationals use capital intensive technology and stay for limited period of time. In contrast, FDI in the manufacturing sector do have higher spillovers potential as it is mostly driven by efficiencyseeking motives. Specifically, labor intensive manufacturing investments will face lower barrier to create horizontal and vertical linkages with domestic firms which facilitates knowledge and technology transfer.

As shown in the figure 2 below, the average, share of FDI to GDP of Sub-Saharan African reaches around 21 percent while the average share of manufacturing and natural resource to GDP becomes 9.9 percent and 8.4 percent respectively. The share of FDI to GDP is higher than the share of Manufacturing to GDP in natural resource rich countries such as Zambia (75 percent), Mozambique (40 percent), Tanzania (33percent) and Nigeria (22 percent) and Ghana (20 percent). The Gross Fixed Capital Formation contribution of FDI is also high in these countries. Therefore, on average, natural resource rich Sub- Saharan African Countries have been receiving higher FDI share to GDP as compared to natural resource poor countries. This is in line with the empirical finding by Asiedu (2005) stating that natural resource-poor countries attracts little FDI as compared to the natural resource rich countries in Sub-Saharan Africa. Accordingly, most of the FDI inflows to Sub-Saharan Africa do have resource-seeking motive than efficiency- seeking; hence, the spillovers effect of FDI in these Sub-Saharan Africa countries is expected to be low.

To sum up, given the increasing inflow of FDI to Sub-Saharan Africa countries, specifically, to resource-rich countries, its contribution for sustainable economic and industrial development depends on the spillovers, linkage and externality effect on domestic firms. 


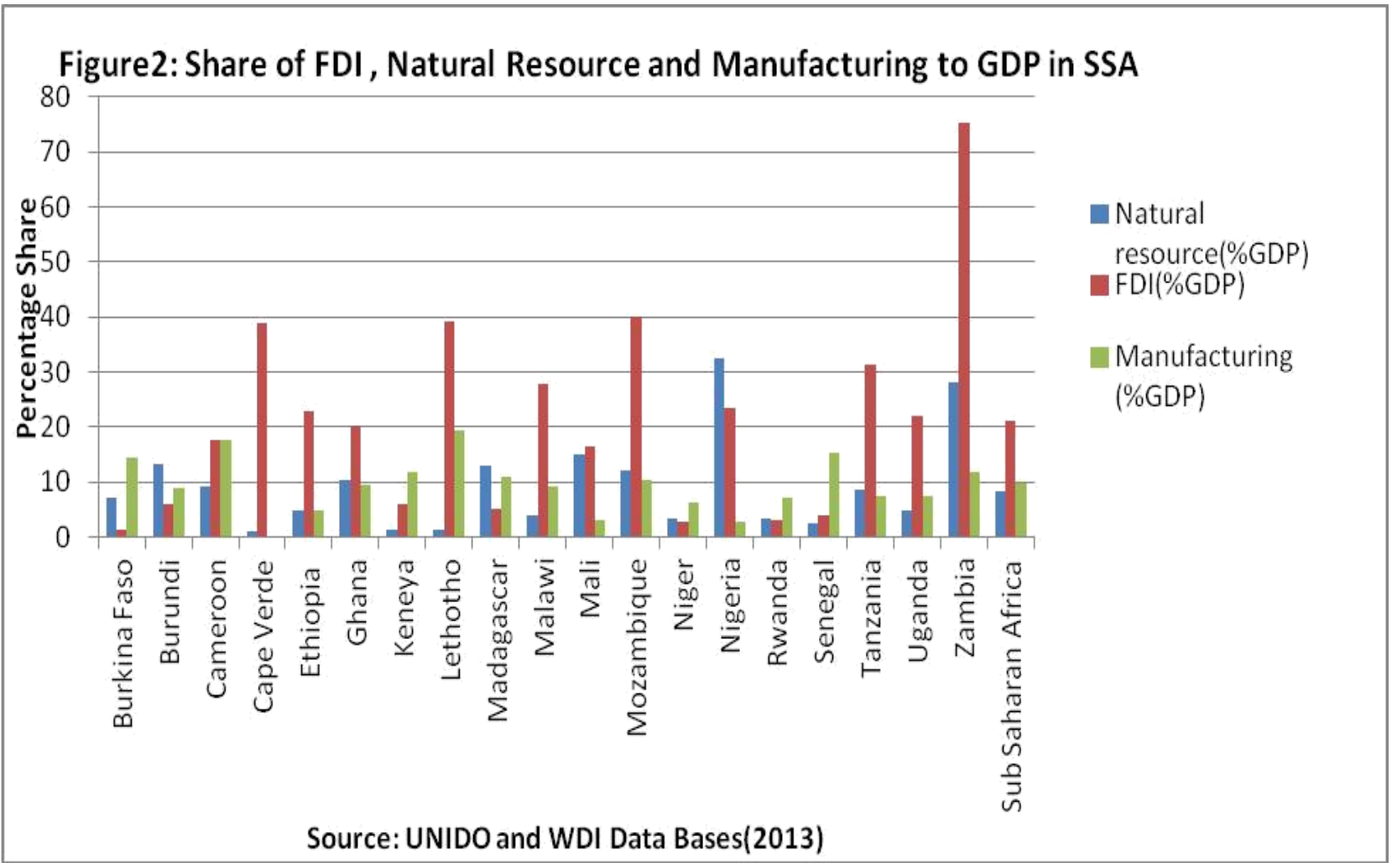

\subsection{The Effects of FDI on Domestic Firms in Sub-Saharan Africa}

This analysis is based on the survey data of UNIDO African Investors Survey 2010. The data is collected from more than 7000 foreign and domestic firms operating in Sub-Saharan Africa countries by taking in to account their size, sector and ownership. Accordingly, the domestic firms rate the effect of the presence of foreign firms on demand for their company's product, cost of labor, availability of factor inputs, access to finance and access to export markets (UNIDO, 2011; Boly et al, 2013).

As shown in the figure 3 below, on average, 40.7 percent of domestic firms in Sub-Saharan Africa are not affected due to the presence of multinationals in the home country. This might be caused by weak linkages of foreign firms with the local firms as foreign firms use less domestic factor inputs and sell lower share of their output in the domestic market. Moreover, the effect of the foreign firm in the export market may not be significant as majority of domestic firms sell their output in the domestic market. Apart from this, the motives of most of FDI undertakings in Sub-Saharan Africa are mainly resource-seeking, exporting primary commodities and service activities with fewer or no spillovers effect on the domestic firms (Boly et al., 2013; Costa da Massingue, 2012). 
On the other hand, on average 34.4 percent and 24.9 percent of the domestic firms in SubSaharan Africa are affected positively and negatively due the presence of multinationals respectively. The positive effect of FDI on local firms exceeds the negative effect for almost all of the Sub-Saharan Africa countries except Lesotho, Ghana, Niger and Uganda. In Mozambique, majority of domestic firms 82.5 percent benefits due to the presence of foreign firms while only 7.2 percent of domestic firms are positively affected by FDI in Lesotho.

The negative spillovers effect in all countries might be attributed to loss of market share due to competitive pressure from multinationals; high labor turnover from domestic to foreign firms caused by wage differential; and increase in cost of labor in the short-run. Moreover, foreign firms may create crowding out effect on domestic firms in the credit market. Even if FDI enhances country's growth performance; there can be a negative employment effect on domestic firms in the short- run (UNIDO, 2012). The positive (27.4) and negative (20.2) spillovers effect of FDI in Ethiopia is less than the Sub-Saharan average. The negative effect on domestic firms might arise from labor mobility from domestic firms to Asian multinationals which dominate FDI in the manufacturing sector of the country.

To sum up, the heterogeneous effect of FDI on the domestic firms across countries can be caused by difference in absorptive capacity of local firms and workers,; FDI spillovers potential of foreign firms, availability of transmission channels, and difference in macroeconomic and institutional environment in which the firms operate. 


\section{Figure3: The Net effects of inward FDI on Domestic Firms in SSA}

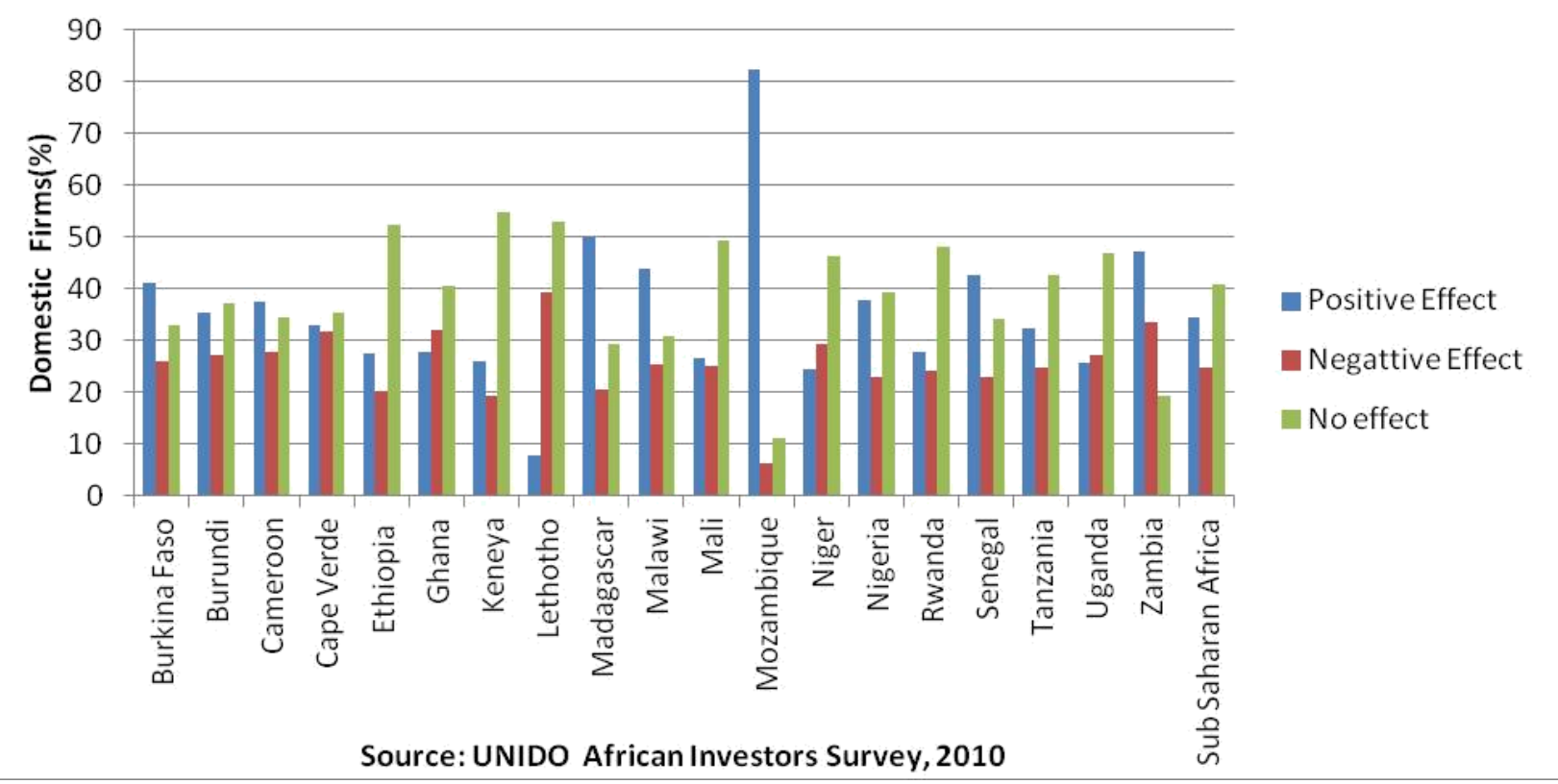

\subsection{Trends of FDI in Ethiopia}

After the overthrow of the previous regime, the existing Ethiopian government took power in the year 1991 and undertakes various policy reforms to shift the country's economy from command to market based. Some of the policy reforms include successive devaluation of currency, elimination of export taxes, lowering import duties from 230 percent to 60 percent, and privatization of some publically owned firms (Ermias, 2013; Henok, 2014). As shown in the figure 4 below, the inward FDI stock to Ethiopia increases from 124.4 million USD in 1990 to 6064.3 million USD in the year 2013. Moreover, the share of FDI to gross capital formation of the country increases from 0.8 percent to in 1990 to 5.7 percent in the year 2013. This increasing trend might be attributed to FDI specific policy reforms by the existing government through establishing Ethiopian Investment Agency; provision of tax and non-tax incentives combined with stable macroeconomic environment (Abeba, 2013).

The establishment of investment agency is a key to overcome the problem of information asymmetry between host country and foreign investors and facilitate the inflow of FDI. Based on the World Bank ease of doing business indicators such as ease of enforcing contracts, availability of infrastructure and credit to start and operate business in the country; 
Ethiopia is ranked at $132^{\text {th }}$ out of 189 countries and its rank is better as compared to its previous position (WB, 2013.)

Ethiopian economy grows rapidly and the country does have a better regulatory environment to start and operate business. As a result of this, the country becomes main destination of FDI in Sub-Saharan Africa. Turkey, India and Chinese firms takes the leading position in FDI inflow to the country, especially, in the manufacturing industry (EIA, 2009). According to the WB (2012) the inflow of FDI from China to Ethiopia has been increasing from zero in 2004 to an annual amount of 58.5million USD in 2010. Sector wise until 2010, the manufacturing sector takes a share of 49 percent of total FDI inflow to the country followed by agriculture(27 percent) and service sectors(24 percent) respectively (Ermias,2013).

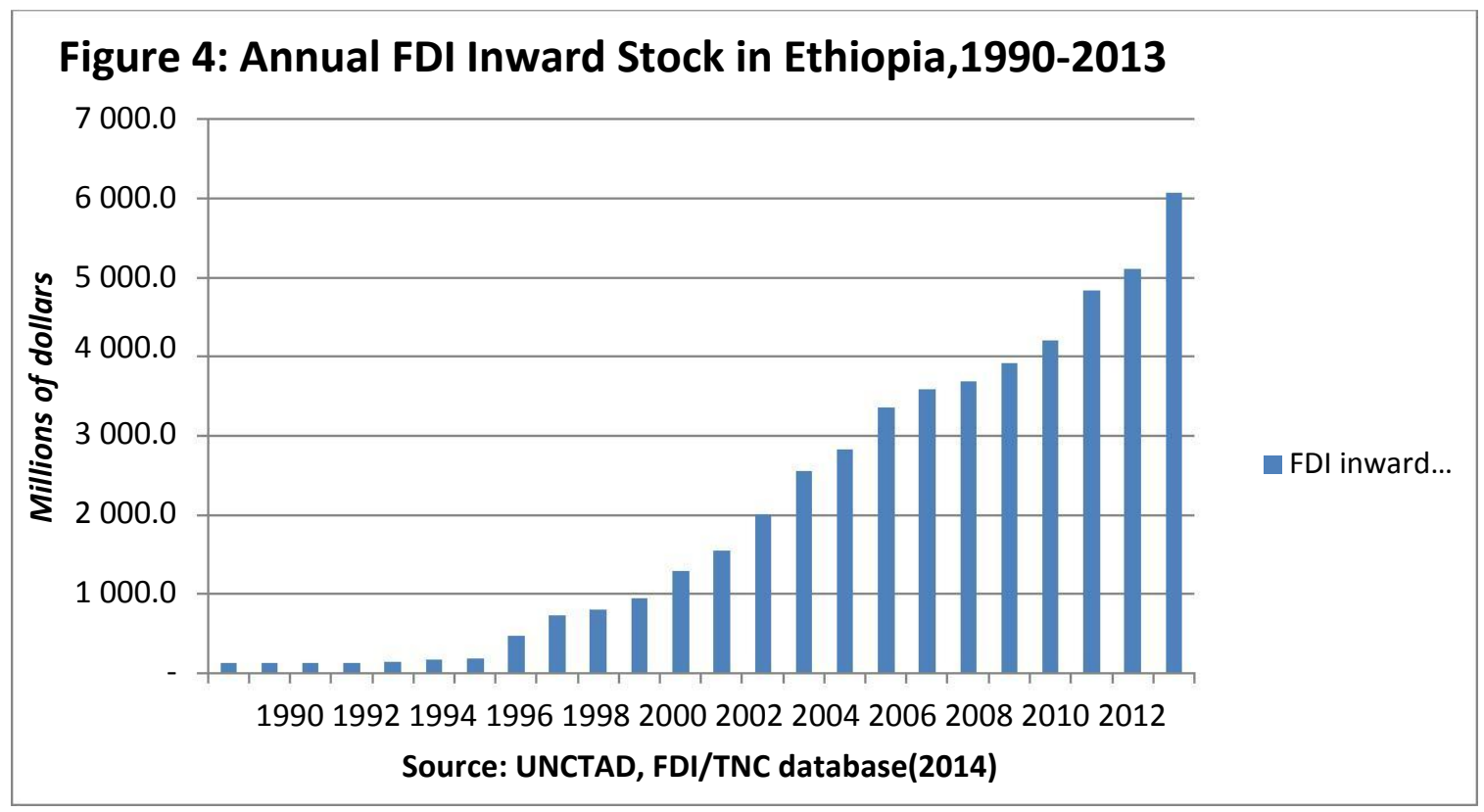

\subsection{Ownership, Sectoral and Regional Distribution of FDI in Ethiopia}

According to the report of EIA (2012) out of the total investment capital in the country in the year 2012/2013 foreign owned projects accounts for 44.2 percent while the remaining 31.1 percent and 24.8 percent is invested by domestic private and government respectively. Similarly, the share of foreign owned projects out of the total number of projects in the country in the same year reach 10.5 percent as compared to 0.5 percent in the year 1992/93. 
As shown in figure 5 below, the share of foreigners out of the total capital formation is increased by 28.2 percent in the year 2012/13 as compared to their respective share in the year 2001/2002.Moreover, the combined share of foreign and domestically owned investment projects out of the total capital formation is higher than the public investment throughout the period under consideration except for the year 2010/2011. This is attributed to privatization of publically owned enterprises domestically and increase in foreign participation through FDI which is the result of private sector development policy reform in the country.

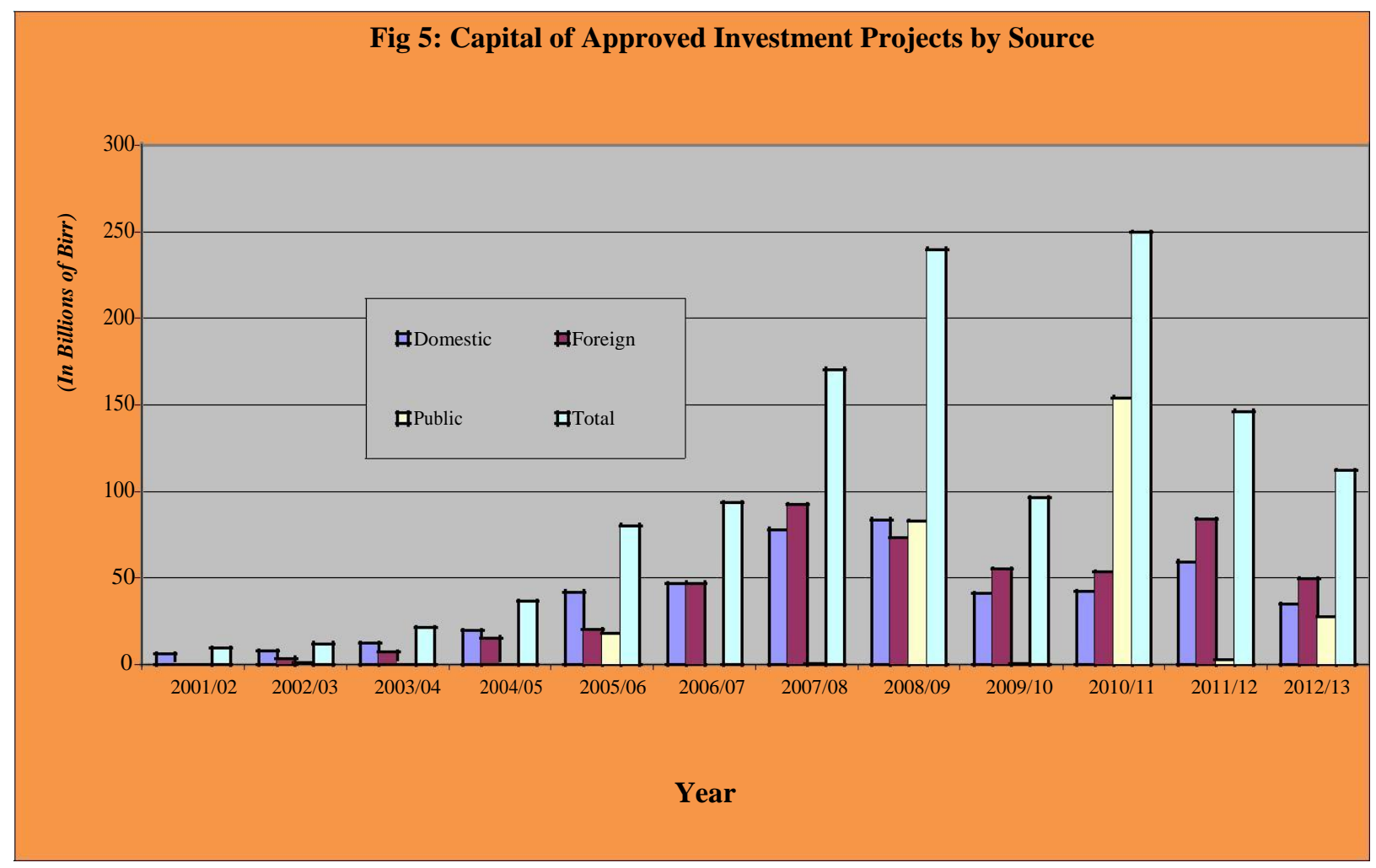

\section{Source: Ethiopian Investment Agency (2013/14)}

Sector wise, for the year 2011/12 and 2012/13, on average, manufacturing sector takes the leading position with 14.3 percent and 31.6 percent share in terms of number of projects and total investment capital respectively. The second larger share of total investment capital (24.7 percent) during the same period goes to gas steam and water supply and electricity. In contrast, the agricultural sector, the major contributor of export and GDP of the country, takes 6.7 and 10.9 percentage share out of the total investment projects and total capital invested in the same year (Annex 15). The largest share of manufacturing sector might be attributed to special tax and non tax related incentive schemes to investors engaged in the 
sector. Some of the incentives include 100 percent exemption from custom duties and taxes, domestic loan up to 70 percent of the investment capital, low land lease rate among others.

Similarly, the contribution of foreign direct investment for generating permanent and temporary employment opportunities of the country also shows an increasing trend. The share of foreign firms out of the total permanent employment of the country is increased by 54.8 percent in the year 2012/13 as compared to the year 2011/12 which was 0.1 percent. Similarly, the contribution of foreign owned firms for temporary employment generation is also increasing. Accordingly, temporary workers hired by foreign firms are increased by 6.7 percent in 2012/13 as compared to the year 2011/12. The number of domestically owned projects is also increased by 7.4 percent in the year 2012/13 relative to the year 2011/12. In contrast, the contribution of domestically owned projects for both permanent and temporary employment opportunity shows a negative change in both periods. This might be the result of drastic decrease in the amount of capital invested (41.3 percent) and laying off workers as firms change their techniques of production (Annex 14).

As far as the regional distribution of FDI is concerned, there is unbalanced regional distribution of investment in Ethiopia. Out of the total approved projects between 2010/11 up to 2012/13,on average,69.7 percent of the projects were located in Addis Ababa, the capital city , 12.1 percent of the establishments were found in Oromia region,11.8 percent were located in Amhara region and the remaining 6.4 percent goes to the rest of the regions (Annex 16). Major proportion of investment projects was concentrated in the capital city due to the relative availability of better infrastructure, skilled workers and political stability (Ermias, 2013).

\subsection{Performance of Manufacturing Sector in Ethiopia}

Following the change in the country's economic system to market based in 1991; the government adopts the Structural Adjustment Programs (SAP).In relation to this, the government undertakes various legal and institutional reforms to enhance the role of manufacturing sector in the Ethiopian economy. The government also designs sector specific policies and strategies to improve the role of manufacturing sector in the industrialization process of the country. However, the contribution of the sector to value added, employment generation, foreign exchange and export earning of the country is still lower as compared to 
the agricultural and service sector of the country as well as the Sub-Saharan average. The share of manufacturing sector to GDP of the country was 4.1 percent in 2000/01 and increased to 4.2 percent in 2012/13 which shows the sectors contribution to GDP of the country remains stagnant (MOFED, 2014).

As shown in table 1 below, the average contribution the manufacturing sector value added to the GDP of the country is 4.9 percent for the last decade which is much lower than the average contribution of the sector's value added to GDP of Sub-Saharan Africa Countries, 13.5 percent. According to the estimation of MOFED (2011) as cited in Melaku et al (2013) out of the value added contribution of the sector to GDP of the country 3.4 percent is obtained from medium and large scale manufacturing and the remaining 1.5 percent is from small and cottage industries. However, the employment contribution of small cottage industries is higher than medium and large manufacturing in the country.

The export share of the manufacturing sector is also lower than the agricultural export share in the country as well as the sector's average contribution in the region. Similarly, the average share of the manufacturing sector output out of the total merchandize export of the country is 9.4 percent which is by far lower than the Sub-Saharan Africa average of 31.8 percent.

The manufacturing import takes the major share of the total merchandise import in the country for the last decade. The share of the manufacturing import out of the total import of the country for the last decade is around 68.9 percent which is higher than the average manufacturing import of Sub-Saharan Africa, 65.9 percent. The low performance of the manufacturing sector might be attributed to the dominance of simple agro-processing and light industries engaged in production of consumer able goods in the sector (Melaku et al, 2013) 
Table 1: Contribution of Manufacturing Sector to GDP, Export and Import of Ethiopia

\begin{tabular}{|l|l|l|l|l|l|l|}
\hline \multicolumn{3}{|c|}{ Ethiopia } & \multicolumn{3}{l|}{ Sub-Saharan Africa } \\
\hline Year & $\begin{array}{l}\text { Value } \\
\text { added } \\
(\% \text { GDP })\end{array}$ & $\begin{array}{l}\text { Export( } \\
\% \text { total } \\
\text { export })\end{array}$ & $\begin{array}{l}\text { Import } \\
(\% \text { total } \\
\text { import })\end{array}$ & $\begin{array}{l}\text { Value } \\
\text { added } \\
(\% \text { GDP })\end{array}$ & $\begin{array}{l}\text { Export } \\
(\% \text { total } \\
\text { export })\end{array}$ & $\begin{array}{l}\text { Import } \\
(\% \text { total } \\
\text { import })\end{array}$ \\
\hline 2000 & 5.5 & 9.8 & 70.9 & 14.9 & 30.7 & 66.6 \\
2001 & 5.7 & 13.4 & 65.2 & 14.9 & 30.5 & 66.1 \\
2002 & 5.7 & 14.3 & 73.9 & 13.7 & 36.6 & 67.9 \\
2003 & 5.7 & 11.4 & 64.0 & 13.8 & 33.8 & 66.2 \\
2004 & 5.3 & 3.8 & 70.8 & 13.7 & 34.1 & 65.1 \\
2005 & 4.9 & 4.6 & 72.0 & 13.2 & 32.3 & 64.3 \\
2006 & 4.5 & 5.4 & 68.5 & 12.7 & 31.2 & 64.2 \\
2007 & 5.0 & 13.8 & 76.4 & 13.6 & 30.5 & 64.9 \\
2008 & 4.8 & 9.0 & 60.2 & 13.3 & 31.1 & 64.1 \\
2009 & 4.0 & 8.7 & 71.5 & 12.7 & 29.5 & 66.8 \\
2010 & 3.9 & 8.9 & 68.7 & 12.4 & 30.7 & 67.0 \\
2011 & 3.6 & 10.4 & 65.3 & 12.6 & 31.6 & 67.2 \\
\hline Average & $\mathbf{4 . 9}$ & $\mathbf{9 . 4}$ & $\mathbf{6 8 . 9}$ & & $\mathbf{1 3 . 5}$ & $\mathbf{3 1 . 8}$ \\
\hline
\end{tabular}

Source: Own Computation from ADI (2013) Database

\subsubsection{Industry Level Value Added Contribution}

As shown in the table (Annex 18), food and beverage industries contribute more than 47.2 percent of the value added of the industrial group followed by non-metallic mineral product industries with 16.4 percent in 2010. The overall value added by the textile and food and beverage industries reach around 50 percent in the same year. The contribution of food and beverage industry to the value added is increased by 21.3 percent in 2010 as compared to the year 2001. According to the CSA (2011/12) survey report around 30.5 percent of the firms in the manufacturing sector are engaged in food and beverage production which also contributes more than 40 percent of the value added and employment. In contrast, the contribution of fabricated metal products, iron and steel, machinery and equipment, and vehicles on average 
contribute around 2.4 percent in 2001 and decreases to less than 2 percent of the value added in 2010 .

\subsubsection{Industry Level Employment Contribution}

The government has been undertaking various policy measures such as tax exemption up to six years for those engaged in food and beverage and textile. In relation to this, there has been rapid inflow of FDI to the manufacturing sector. The contribution of food and beverage industry mainly plays pivotal role in generating high industry level employment.

As shown in figure 6 below, the share of food and beverage industries out of the total manufacturing industry employment reaches around 31.8 percent in the year 2010. Similarly, the contribution of the other non-metallic mineral products reaches around 11.1 percent which shows a 45 percent increment relative to the year 2003. The government sets a target of reaching $\$ 1 b n$ in the textile and apparel export in 2016 and the sector is expected to generate more employment opportunities (EIA, 2010). In response to policy incentives more

and more Chinese, Turkey and Indian investors has been joining the textile industry. Despite the incentives provide to support the industry, the share of the industry out of the total employment in the sector is only 12.6 percent in 2010 .

On the other hand, the average employment contribution of the basic iron and steel, fabricated metal products, machinery and equipment, and vehicles together increases from 1.3 percent in the year 2003 to 1.85 percent in 2010.The contribution of these sectors shows insignificant improvement for the last few years. According to Melaku (2013) lack of finance, inefficiency and dependence on light industries limits the contribution of these sectors to employment as well as value added. 


\section{Figure 6: Share of Employment by Major Industrial Group}

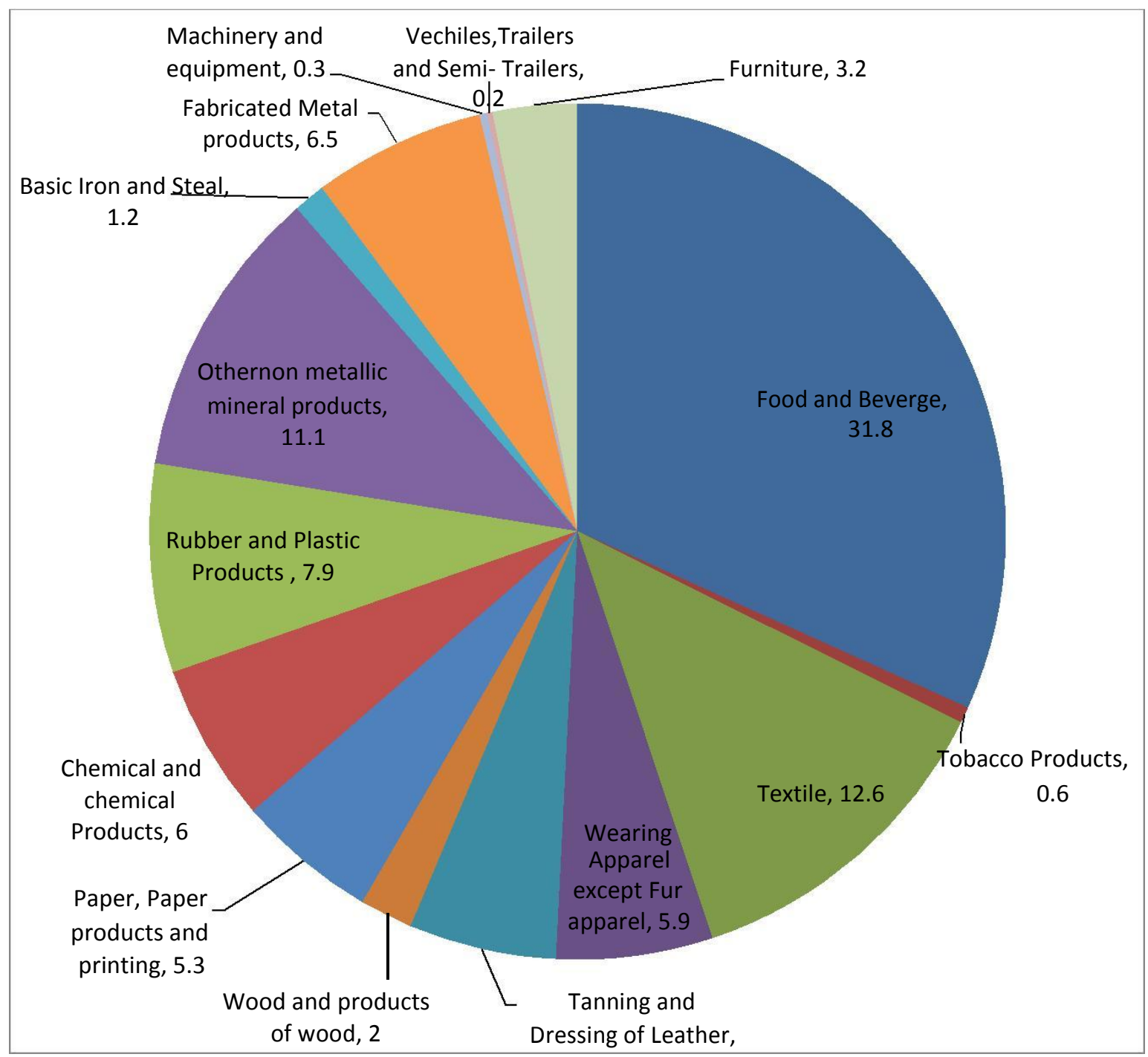

\section{Source: Own Computation from CSA data set (2010)}

To sum up, the average contribution of capital intensive industries mainly metal, iron and steel, machinery and equipment to the value added and employment is less than 3 percent during the period under consideration. Therefore, using labor productivity as a proxy to measure the total factor productivity in our empirical analysis is appropriate as majority of the industries contributing significant portion of the value added and employment are labor intensive. 


\section{Model Specification, Estimation Results and Discussion}

\subsection{Methodology and Data}

\subsubsection{Data Description}

In this study, we use the unbalanced panel dataset of large and medium scale manufacturing firms in the Ethiopia collected by Central Statistics Authority (CSA) of the country for the period 2003 to 2010. These surveys are confined to those establishments which engage 10 persons and above and use power-driven machines for the production which covers both the private, public and foreign owned industries in all regions of the country. The data set covers a wide range of information on wages and salaries paid, number of persons engaged, total value of sales, value of raw materials, value of intermediate inputs, value of stocks and fixed assets, quantity and value of production, investment by type and source of individual firms in the manufacturing sector among others.

In this study, we consider industries with ISIC code from 1511 to 3610. Firms with in this range are categorized under manufacturing as per the International Standard Industrial Classification (ISIC) Revision 4.1. The number of firms per year varies from a low of 730 in 2004 to high of 1863 in 2009 . After deleting those observations with zero sales, zero employment, zero output, and missing values; a total of 11131 observations categorized under 52 manufacturing industries are included in the period under consideration. Regarding ownership, firms are classified as foreign owned and domestically owned based on their respective share of issued capital out of the total paid up capital. Accordingly, firms having the capital share of 10 percent and above are considered as FDI based on UNCTAD and OECD classification.

GDP deflator is used to construct the real value of the variables included in our model. The firm-level data is used in combination with host country level factors and institutional framework to assess the impact of the interaction term with FDI spillovers on productivity of manufacturing firms. Moreover, WDI, ADI and Heritage foundation databases are used for the host country factors and institutional framework data. 


\subsubsection{Methodology}

In this study, panel data econometric analysis is used to assess the spillovers effect of the foreign firm presence and its interaction with host country factors and institutions on productivity of domestic firms. The magnitude and extent of FDI spillovers from multinationals can be analyzed quantitatively by observing the changes on productivity of domestic firms due to the presence of foreign firm. Moreover, descriptive analysis is used to show the general trend of total FDI inflow, sectoral distribution, performance and contribution of manufacturing industries in the country.

\subsection{Model Specification and Definition of Variables}

\subsubsection{Model Specification}

From the model used by Blalock and Gertler (2009) as cited in Farole and Winkler (2012) the baseline model to be estimated is given as:

$\operatorname{Prod}_{i j t}=B_{0}+B_{1} F I_{j t}+B_{2} F D I E_{j t}+B_{3} F_{1 j t} * M F+e_{i j t}$

Prodijt: is measure of productivity of firm $i$ in industry $j$ at time $t$

FDIjt: is horizontal spillover variable based on value of output to capture the foreign firm presence in industry $\mathrm{j}$ at time $\mathrm{t}$. This measure shows the productivity effect through channels of horizontal transfer, other than labor mobility.

FDIE $_{\mathrm{jt}}$ : is horizontal spillovers variable based on employment to capture the labor mobility effect of foreign firm presence in industry $j$ at time $t$.

FDI $\mathbf{j}_{\mathbf{t}} * \mathbf{M F}$ : is measure of interaction term of horizontal spillover variable with host country factors and institutional framework as a mediating factor.

eijt: is idiosyncratic error term

In order to come up with more parsimonious model and isolate the net horizontal spillovers effect of foreign firm presence; we incorporate other control variables affecting the productivity of domestic firms to the original model. The extended model to be estimated is given as:

$\operatorname{Prod}_{\mathrm{ijt}}=\mathrm{B}_{0}+\mathrm{B}_{1}$ FDI $_{\mathrm{jt}}+\mathrm{B}_{2} \mathrm{FDIE}_{\mathrm{jt}}+\mathrm{B}_{3}$ FDI $_{\mathrm{jt}} * \mathrm{MF}+\mathrm{B}_{4}$ Control $_{\mathrm{ijt}}+\mathrm{D}_{\mathrm{j}}+\mathrm{D}_{\mathrm{i}}++\mathrm{e}_{\mathrm{ij}}$

Controlijt: is vector of observable control variables 
$\mathbf{D}_{\mathbf{j}}$, and $\mathbf{D}_{\mathbf{i}}$ : are firm fixed effects and industry fixed effects respectively. These variables are included in the model to capture unobserved factors that affect the correlation between foreign firm presence and the productivity of domestic firms. This includes difference in access to infrastructure and attractiveness of a particular industry; management quality differences which are not explicitly included by econometricians but affects productivity of firms (Javorcik, 2004).

The observable control variables and unobserved firm and industry fixed effects are included in the model in order to isolate the net effect of FDI spillovers after controlling other factors affecting productivity.

\subsubsection{Definition of Variables}

\subsubsection{Dependent Variable}

Productivity (Prodijt): in this study, the firm level productivity is proxide by labor productivity which is value added per worker (Farole and Winkler, 2012; Shiferaw and Tadele, 2015). Value added can be calculated by deducting cost incurred for materials and intermediate goods and services from total value of sales (Rao and Tesfahunegn, 2015).

According to Rao and Tesfahunegn (2015) it is rational to use labor productivity to measure the performance of the firms as labor is the one that manipulates the productivity of all other factors in the firm. Moreover, labor productivity is appropriate to measure level of productivity in the labor intensive industry as it shows the efficiency and effectiveness of labor in the production as well as sales process. Therefore, as manufacturing industries in Ethiopia are labor intensive; labor productivity is appropriate to measure overall factor productivity in our model.

\subsubsection{Explanatory Variables}

FDI ${ }_{j t}$ : is the output measure of intra-industry FDI presence in industry $\mathrm{j}$ at time $\mathrm{t}$ (Proxy for horizontal spillovers). The coefficient of the horizontal spillover variable shows the change in productivity of manufacturing firms caused by increase in foreign firm presence in same sector (Havranek and Irsova, 2011). This variable captures the effect of other channels of horizontal transfer after controlling for workers mobility channel and other observable and unobservable factors affecting productivity. 
Based on the work of Farole and Winkler (2012), Javorcik (2004) output measure of intraindustry FDI presence at industry level at time $t$ is used as one proxy for horizontal Spillover. The horizontal spillovers is calculated by using share of foreign firms output out of the industry $\mathrm{j}$ output at time $\mathrm{t}$ which captures the presence of foreign firms in the industry $\mathrm{j}$ at time t.

Horizontaljt (FDIjt) $=\epsilon$

$\mathbf{Y}_{\mathbf{j t}}$ is the total output of industry $\mathbf{j}$ at time $\mathrm{t}$.

$\mathbf{Y}_{\mathbf{i j t}}$ is the output of foreign firm $\mathrm{i}$ in industry $\mathrm{j}$ at time $\mathrm{t}$

We consider the firm as foreign with the foreign capital share of 10 percent or higher (Farole and Winkler, 2012; Jude, 2013). Horizontal spillovers increase with the increase in output and equity share of foreign firms within the industry (Javorcik, 2004; Jude, 2013).

Most multinationals invest on employees' knowledge and skill development training. According to Fosfuri et al (2001) knowledge transfer takes place as long as domestic firms bid and hire these employees of foreign firms who are exposed to new technologies and accumulate knowledge. Therefore, the other horizontal variable through which intra-industry knowledge spillover can be undertaken through mobility of employees. According to Merlevede and Schoors (2007) the labor mobility effect of foreign firm presence within the industry can be calculated as:

\section{Horizontal_E $($ FDIE $\mathbf{j t})=$}

Ejt: is total number of employees in the manufacturing industry $\mathrm{j}$ at time $\mathrm{t}$

$\mathbf{E}_{\mathrm{ijt}}$ : is number of employees of in foreign firm $\mathrm{i}$ in industry $\mathrm{j}$ at time $\mathrm{t}$

According to Jude (2013) labor mobility channel of horizontal transfer is based on the assumption that all employees of multinationals acquire and accumulate knowledge when they shift to domestic firms.

FDI $_{\mathbf{j t}}$ *MF : is the interaction of measure of horizontal spillovers variable with vector of mediating factors. In this model, we include selected host country factors and institutional framework as mediating factors .The components of measure of economic freedoms as 
explained by heritage foundation taken in natural logarithms is used to represent institutional framework variables. Moreover, GDP of the country and human capital stock will be included in the model as a mediating factor.

Labor (labct): represents quantitative measure of labor freedom to capture the labor market institutions in the country at time $\mathrm{t}$. The measure includes the various aspects of legal and regulatory framework of the country's labor market such as measurable of regulatory hurdles of hiring workers, rigidity of hours, and minimum wage legislation among others. The variable ranges from lowest score 0 to the highest score 100 for labor freedom.

Finance (finct): represents measure of overall level of financial freedom in the country at time t. It measures banking efficiency as well as government control and interference in the financial sector which affects access to financing opportunities. The measure ranges from the lowest score 0 to 100 which shows highest financial freedom.

Property rights (Prpct): measures the degree of legal protection of private property in the country at time t which affects the firm's ability to accumulate private property. The score ranges from 0 to 100 (more certain legal protection of private property).

Business (busct): represents measure of business freedom in the country at time t. The quantitative measure for business freedom is derived from measuring difficulty of starting, operating and closing the business based on the World Bank doing business study. The measure ranges from the lowest score 0 to 100 (highest business freedom).

Investment (invet): represents measure of investment freedom used to capture the ability of firms to move their resources in and out of a specific activity both internally and across the country's boarder. The measure evaluates variety of restrictions typically imposed on investment is based on the government publications on capital flows and FDI. The score ranges from 0 to 100 which show the highest investment freedom.

Openness (Openct): the share of sum of exports and imports to GDP of the country at time $t$ which captures the degree of trade openness.

Human capital (humct): the tertiary and secondary school enrollment rate in the country at time $\mathrm{t}$ which is measured by people completed secondary and tertiary education as percentage of total population obtained from ADI data base. 
Gross Domestic Product (GDPct): The country's per capita GDP at time $\mathrm{t}$ in natural logarithms which captures the country level competition and other aspects of national environment (Farole and Winkler, 2012).

Apart from the above interaction variables; the following control variables are incorporated in the model:

Firm size (Sizeijt): is size of firm $i$ in industry $j$ at time t proxide by firm's total number of employees. Firm size captures the economies of scale. The larger the firm, the higher will be the production volume and the firm becomes cost efficient and productive (Jude, 2013).

Herfindhal-Hirschmaan Index (HHijt): represents sector concentration to capture degree of competition in the domestic manufacturing sector $\mathrm{j}$ at time $\mathrm{t}$. It is measured by using the sum of squares of firm's value of revenue share out of the industry level revenue. The entry of foreign firms in the market may decrease the industry concentration and enhance competitiveness and forcing domestic firms to improve productivity. This measure, therefore, captures the effect of sector level concentration on productivity of firms.

HHI for both domestic and foreign firms is computed by using the following formula $\mathrm{HHI}=\sum \quad(-\quad)^{2}$

$\mathrm{TR}_{\mathrm{ij}}$ is the total revenue of firm $\mathrm{i}$ industry $\mathrm{j}$ at time $\mathrm{t}$

$\mathrm{TR}_{\mathrm{j}}$ is the total revenue of industry $\mathrm{j}$ at time $\mathrm{t}$.

Capital Intensity(Capijt): represents measure of capital intensity of firm i in industry j at time t. Capital in this model is represented by real net tangible capital at the end of the year which shows the value of fixed assets at the end of the year. Therefore, capital intensity is measured by ratio of value of fixed assets to total number of employees.

Ageijt : is age of the firm $i$ in industry $j$ at time t. Age of the firm is calculated by deducting year of commencement from the year when the survey is conducted. 


\subsection{Model Estimation Issues}

\subsubsection{Hausman Specification Test}

The specification test devised by Hausman (1978) is used to test for orthogonality of the random effects and the regressor's and chooses between the random effects and fixed effects model. In this study the Hausman specification test is used to choose between the fixed effects and the random effects model. Under Hausman specification test the null hypothesis is difference in coefficients is not systematic while the alternative hypothesis is there is a systematic difference in coefficients (Greene, 2003). The resulting test statistics of the Hausman specification test (Annex2) shows the p-value is zero implying that we fail to accept the null hypothesis, therefore, fixed effects estimation technique is appropriate for this model.

\subsubsection{Heteroskedasticity Test}

Assuming homoskedastic disturbances when heteroskedasticity is present result in consistent estimates of the regression coefficients; but these estimates will not be efficient. The loss of efficiency leads to biased standard error and hence the inferences from this estimate become invalid (Baltagi, 2005). In this study modified wald test for group wise heteroskedasticity is used. Under this test the null hypothesis is the error term is homoskedastic while the alternative is heteroskedasticity of the error term. The resulting test statistics (Annex3) shows that we reject the null hypothesis of homoskedasticity of the error term. Therefore, robust option is added to the fixed effects estimation to control for hetroscedasticity

\subsubsection{Test for Autocorrelation}

When the covariance between two or more consecutive error terms is correlated we say that the error term is subject to autocorrelation (Veerbek, 2000). If there is autocorrelation in the data the estimates become inefficient and standard errors are estimated in the wrong way. In this study, Wooldridge test for autocorrelation in panel data is used to check the presence of autocorrelation. The null and alternative hypotheses of Wooldridge test for autocorrelation in panel data are no first-order autocorrelation and the null hypothesis is not true respectively. The resulting test statistics (Annex 4) shows that so we fail to reject the null hypothesis at 1 percent and 5 percent significance level implying that no first order autocorrelation. 


\subsubsection{Test for Multicollinearity}

High correlations between explanatory variables may result in multicollinearity problem. If there is multicollinearity in the model dropping one or more correlated variables from the model can be used as the remedial measure (Veerbek, 2000). In this study, the presence of multicollinearity in the model is checked by using variance covariance matrix. After assessing the cross correlation of all institutional and national characteristics variables; dropping highly correlated variables such as property right index, business freedom index

and per capita GDP is taken as a remedial measure. This measure reduces multicollinearity but it does not eliminate it at all. Presence of some degree of collinearity in the model should not be surprising as the spillovers variable, measured at the industry level, is interacted with institutional variables which are measured at the country level as a result most of the variation may come from institutional variables. According to (Williams, 2015) multicollinearity is common in a model containing variables that are computed from other variables. (Clark, 2013) revealed that when multicollinearity is problem very high standard errors, overly sensitive regression coefficients and low t-statistics are likely to occur which is not the case in our model

\subsubsection{Test for Endogeneity}

Endogeniety occurs when the independent variable is correlated with the error term in the regression model. The error term and explanatory variables will be correlated when all the explanatory variables are not explicitly included in the model or when there is omitted variable bias. One can check the presence of endogeneity problem in model by inspecting the correlation matrix between the residuals and the explanatory variables. In this model, the correlation coefficient between the error term and the explanatory variables is less than 0.5 which shows no potential endogeniety problem in our model (Annex 5). 


\subsection{Estimation Results and Discussion}

In this section, all the main estimation results of the model are presented. The fixed effects estimator is preferred after conducting the Hausman specification test. The dependent variable is regressed over the FDI spillover variables consisting of labor mobility, other channels of horizontal spillovers, the interaction terms and other control variables. In order to capture the net spillovers effect of foreign firm presence on productivity, in our econometric analysis, we include other observable factors affecting the productivity of domestic firms. After testing their respective significance industry specific and firm specific effects are also incorporated in the model to capture unobserved factors affecting productivity. The firm and industry specific effects are included to control factors such as the effect of location and attractiveness of particular industry on the productivity of firms. Moreover, lagged spillovers variable is also included in the model as the spillovers effect of foreign firm presence on the productivity of domestic firms may take time to manifest.

The fixed effects estimation results for the baseline model containing only the horizontal spillovers variables and the interaction terms as an explanatory variable (Model 1) and the model incorporating observable control variables in addition to variables incorporated in the baseline model (Model 2) is presented below. In estimating both models, robust option is used to control the problem of hetrosedasticity. 
Table 2: Fixed Effects Estimation for Model 1 and Model 2

Dependent Variable- labor productivity (2003-2010)

\begin{tabular}{|c|c|c|}
\hline & $\begin{array}{l}\text { Model } 1 \\
\text { (Baseline Model ) }\end{array}$ & $\begin{array}{l}\text { Model } 2 \\
\text { (Model with control variables) }\end{array}$ \\
\hline$\overline{\left(F D I_{j t}\right)}$ & $\begin{array}{l}4.881 * * * \\
(0.7910)\end{array}$ & $\begin{array}{c}.501 * * * \\
(0.7291)\end{array}$ \\
\hline (FDIEjt) & $\begin{aligned}- & 0.001 \\
& (0.0024)\end{aligned}$ & $\begin{aligned} &- 0.002 \\
&(0.0024)\end{aligned}$ \\
\hline$\left(\mathrm{FDIE}_{\mathrm{j}} * \mathrm{lab}_{\mathrm{ct}}\right)$ & $\begin{array}{c}-1.428 * * * \\
(0.2270)\end{array}$ & $\begin{array}{r}-1.006 * * \\
(0.2088)\end{array}$ \\
\hline$\left(\mathrm{FDI}_{\mathrm{jt}} * \mathrm{fin}_{\mathrm{ct}}\right)$ & $\begin{array}{l}0.011 \\
(0.3492)\end{array}$ & $\begin{array}{l}0.060 * * \\
(0.0175)\end{array}$ \\
\hline$\left(\mathrm{FDI}_{\mathrm{jt}} *\right.$ Open $\left._{\mathrm{ct}}\right)$ & $\begin{array}{l}1.913 * * * \\
(0.3827)\end{array}$ & $\begin{array}{l}0.012 \\
(0.0373)\end{array}$ \\
\hline$\left(\mathrm{FDI}_{\mathrm{jt}} * \mathrm{hum}_{\mathrm{ct}}\right)$ & $\begin{array}{l}0.105^{* * *} \\
(0.0247)\end{array}$ & $\begin{array}{l}0.115^{* * *} \\
(0.2471)\end{array}$ \\
\hline$\left(\mathrm{FDI}_{\mathrm{jt}} * \mathrm{inv} \mathrm{ct}\right)$ & $\begin{array}{l}-0.033 * * * \\
(0.0066)\end{array}$ & $\begin{array}{c}0.032 \\
(0.0067)\end{array}$ \\
\hline (HHIijt) & & $\begin{array}{l}0.001 \\
(0.0009)\end{array}$ \\
\hline (Capijt) & & $\begin{array}{l}0.193 * * * \\
(0.0148)\end{array}$ \\
\hline (Age $i j t)$ & & $\begin{array}{l}0.258 * * * \\
(0.0729)\end{array}$ \\
\hline$($ Sizeijt $)$ & & $\begin{array}{l}-0.356^{* * *} \\
(0.0442)\end{array}$ \\
\hline Constant & $\begin{array}{c}6.113 * * * \\
(1.317)\end{array}$ & $\begin{array}{l}5.3218 * * * \\
(0.263)\end{array}$ \\
\hline $\begin{array}{l}\text { Observations } \\
R \text {-Squared }\end{array}$ & $\begin{array}{l}9324 \\
0.04\end{array}$ & $\begin{array}{r}8994 \\
0.16\end{array}$ \\
\hline
\end{tabular}

Note: $* p<0.05 ; * * p<0.01 ; * * * p<0.001$ Robust standard errors in Parentheses 
As shown in table 2 above, the two columns present the regression results of the baseline model (Model 1) and the model with additional control variables (Model 2).The joint significance test result for control variables shows that the variables are significant (Annex 8). Moreover, the goodness of fit result also shows that the explaining power of the explanatory variables is better in the model containing observable control variables than the baseline model. The magnitude of the coefficients and standard errors are lower in the model with control variables implying that the biasness of estimators is lower in the extended model relative to the baseline model.

To test the robustness of the results, we alternatively remove control variables to check whether the sign or significance of horizontal spillover variables change in the absence of some control variables the result remains the same as the horizontal spillover variables are very robust. We also check the robustness of the model by incorporating the interaction variables one by one. The result shows that the sign and significance of the spillover variables as well as the interaction terms will not be changed in the process which also shows the robustness of the model. This result also indicates that the suspected multicollinearity problem among the interaction terms does not affect the sign and significant of the explanatory variables (Annex 9).

In order to isolate the net effect of productivity spillovers, the model incorporating firm specific and industry specific effects is estimated after checking their respective significance The significant test result indicates that unobservable factors such as location and attractiveness of a particular firm or industry affects productivity. Therefore, we control this effect by incorporating firm specific and industry specific fixed effects (Annex 10).

Table 3 below presents the fixed effects estimation result of the model with interaction and observable control variables (Model 2) and the model incorporating industry and firm specific fixed effects in addition to the interaction and control variables (Model 3). The estimation result of Model 3 is more reliable as it shows the net FDI spillover effect on productivity after controlling both observed and unobserved factors affecting domestic firms' productivity. 
Table 3: Fixed Effects Estimation for Model 2 and Model 3

Dependent Variable- labor productivity (2003-2010)

\begin{tabular}{|c|c|c|}
\hline & $\begin{array}{c}\text { Model } 2 \\
\text { (with control variables) }\end{array}$ & $\begin{array}{c}\text { Model } 3 \\
\text { (with entity fixed effects) }\end{array}$ \\
\hline$\left(F D I_{j t}\right)$ & $\begin{array}{l}3.501 * * * \\
(0.7291)\end{array}$ & $\begin{array}{l}5.364 * * * \\
(0.7247)\end{array}$ \\
\hline (FDIEjt) & $\begin{array}{l}-0.002 \\
(0.0024)\end{array}$ & $\begin{array}{l}-0.0054 * \\
(0.0024)\end{array}$ \\
\hline$\left(\mathrm{FDIE}_{\mathrm{jt}} * \mathrm{lab}_{\mathrm{ct}}\right)$ & $\begin{array}{r}-1.006^{* *} \\
(0.2088)\end{array}$ & $\begin{array}{c}-1.539 * * * \\
(0.2057)\end{array}$ \\
\hline$\left(\mathrm{FDI}_{\mathrm{jt}} * \mathrm{fin}_{\mathrm{ct}}\right)$ & $\begin{array}{l}0.060 * * \\
(0.0175)\end{array}$ & $\begin{array}{l}0.047 * \\
(0.2108)\end{array}$ \\
\hline$\left(\mathrm{FDI}_{\mathrm{jt}}{ }^{*}\right.$ openct $\left._{\mathrm{ct}}\right)$ & $\begin{array}{l}0.012 \\
(0.0373)\end{array}$ & $\begin{array}{l}0.1048 * \\
(0.4261)\end{array}$ \\
\hline$\left(\mathrm{FDI}_{\mathrm{jt}} *\right.$ humct $\left._{\mathrm{c}}\right)$ & $\begin{array}{l}0.115^{* * *} \\
(0.2471)\end{array}$ & $\begin{array}{l}0.1129 * * * \\
(0.0252)\end{array}$ \\
\hline$\left(\mathrm{FDI}_{\mathrm{jt}} * \mathrm{inv}_{\mathrm{ct}}\right)$ & $\begin{array}{l}0.032 \\
(0.0067)\end{array}$ & $\begin{array}{l}0.009 \\
(0.057)\end{array}$ \\
\hline (HHIijt) & $\begin{array}{l}0.001 \\
(0.0009)\end{array}$ & $\begin{array}{l}0.004 \\
(0.0114)\end{array}$ \\
\hline (Capijt) & $\begin{array}{l}0.193 * * * \\
(0.0148)\end{array}$ & $\begin{array}{l}0.247 * * * \\
(0.0964)\end{array}$ \\
\hline (Age $\mathrm{Aijt})$ & $\begin{array}{l}0.258 * * * \\
(0.0729)\end{array}$ & $\begin{array}{l}0.254 * * * \\
(0.0354)\end{array}$ \\
\hline (Sizeijt) & $\begin{array}{l}-0.356 * * * \\
(0.0442)\end{array}$ & $\begin{array}{l}-0.0367 * \\
(0.0178)\end{array}$ \\
\hline Constant & $\begin{array}{l}5.3218^{* * *} \\
(0.263)\end{array}$ & $\begin{array}{l}5.0945 * * * * \\
(0.796)\end{array}$ \\
\hline $\begin{array}{l}\text { Observations } \\
R \text {-Squared } \\
\text { Industry Fixed Effects } \\
\text { Firm fixed effects }\end{array}$ & $\begin{array}{l}8994 \\
0.16 \\
\text { No } \\
\text { No }\end{array}$ & $\begin{array}{c}8994 \\
0.48 \\
\text { Yes } \\
\text { Yes }\end{array}$ \\
\hline
\end{tabular}

Note: $* p<0.05 ; * * p<0.01 ; * * * p<0.001$ Robust standard errors in Parentheses 
As we can see from the above estimation result (table 3), apart from the observable control variables the inclusion of the unobservable firm and industry fixed effects in Model 3 increases the goodness of fit of the model. We did not find a difference in sign of the coefficients in the two models. However, the labor mobility effect of foreign firm presence (FDIE) becomes significant after we control for unobserved firm and industry level heterogeneity. Similarly, the interaction of horizontal spillovers variable with degree of openness becomes significant when we incorporate firm and industry fixed effects in our estimation. Moreover, in both models, the effect of the interaction of spillovers variable with investment freedom index of the country $(F D I * i n v)$ and sectoral concentration index (HHI) on productivity remains not significant but positive.

As we can see from the result in the above table 3, both estimates produce a positive and significant coefficient for horizontal spillovers variable other than the labor mobility channel $(F D I)$. The result reiterates that productivity effect of technological transfer through channels other than labor mobility is not only positive but also relatively large in magnitude which is almost similar with the firm level study finding by Farole and Winkler (2013). This might be the result of technology diffusion from foreign firms to domestic firms arising from proximity and interaction; as most manufacturing firms in Ethiopia are located in similar industrial zone with the foreign industries. Therefore, exposition to marketing strategies, production process and distribution networks of multinationals enhances the productivity of domestic firms. The result is consistent with the previous finding by Ermias (2013).

According to (Javorcik,2004b) the spillovers through imitation will be more effective when firms produce similar products. This is also true for the case of manufacturing industry in Ethiopia as the Chinese, Indian and Turkey companies, which produces closely substitute products with the Ethiopian firms, dominates the industry. Moreover, the positive spillovers effect might be attributed to the lower technological gap between domestic and foreign firms The finding by (Amighini and Sanfilippo,2014) revealed that technological spillovers from South-South FDI is potentially positive as smaller technological gap increases the chance to absorb spillovers by the local firms. 
Most of the empirical studies do not isolate the labor mobility and other channels of horizontal transfer, arguing that what matters is the net effect (Jude, 2013). However, by analyzing only the net effect of FDI spillovers we do not know whether horizontal knowledge spillovers through labor mobility channel is positive or negative.The labor mobility effect of FDI spillovers might be either negative or positive depending on the capacity of domestic firms to attract workers working in multinationals (Farole and Winkler,2012). The estimation result (Model 3) shows that horizontal spillover through the labor mobility channel negatively affects productivity of domestic firms and it is also significant. The result is contrary to empirical study by Jude (2013) and Merlevede (2007) on Romanian firms and Balsvik (2011) on Norwegian manufacturing firms.

According to Farole et al (2014) and Hoekman and Javorcik (2006) the short-run labor mobility effect will be reversed in the medium term as skill and knowledge of workers may not be completely internalized by multinationals. Accordingly, we re-estimate the model by incorporating the lagged value of the spillovers variable through labor mobility (LFDIE)) in the model. The result is remaining negative but insignificant (Annex 12). Therefore, the short-run labor mobility from domestic to foreign firms with in the manufacturing industry will not be reversed at least in one year. This is attributed to high wage and benefit package gap between domestic and foreign firms in the country which results in labor turnover to foreign firms and forces domestic firms either to pay higher wage or hire less productive workers. According to (Lipsey et al., 2004) spillovers through labor mobility to domestic firms is lower in low income countries as there is high wage differential between multinationals and domestic firms. Similarly, Lipsey and Sjoholm (2004) reiterated that multinationals tend to pay more for labor of a given quality than domestic firms.

As far as the role of the mediating factors is concerned, the result is in line with our priori expectation. Labor market regulation affects the frequency and nature of transmission of FDI spillovers in to domestic firms. As we can see from the result in table 3 above, the interaction of labor mobility channel of horizontal transfer with labor freedom index (FDIE*lab) results in a significantly negative effect on productivity of domestic firms. This might be the outcome of highly flexible labor market regulation in the country. According to Farole and Winkler (2012) and Hale and Long (2011) highly flexible labor market results in frequent turnovers which reduces chance for acquiring spillovers from multinationals. It is also a disincentive for domestic firms to invest in job training which, in turn, adversely affects their 
respective absorptive capacity. Therefore, highly flexible labor market regulation in the country in general and wage constraint of firms in particular facilitates labor mobility from domestic to foreign firms. Similar conclusion is reached by Hale and Long (2011) on their study on labor mobility effect of FDI in china on domestic firms.

In contrast, the other mediating factors interact positively with the horizontal spillovers variable. According to Hermes and Lensink (2003) as cited in Crespo and Fontoura (2007) financial sector efficiency and development positively mediates FDI spillovers as it enhances the capacity to imitate technologies and upgrade employees qualification. As shown in the above table, Model 3, the interaction of FDI spillovers variable with financial freedom and development $\left(F D I^{*}\right.$ in $\left.)\right)$ shows a positive and statistically significant effect on the productivity of domestic firms. In relation to the program of transforming the country in to "manufacturing power house"; credit priority is given to domestic investors' engaged in labor intensive manufacturing industries in Ethiopia. Moreover, the expansion of banking industry in Ethiopia improves credit availability for domestic firms. This facilitates the domestic firms' absorptive capacity and reduces the risk of investment to imitate technology as well as enhances spending on workers job training. The finding is in line with the firm level study result by Farole and Winkler (2012) and Agarwal et al (2011).

The extent of FDI spillovers also depends on the nature of trade policy regime. As we can see from the estimation result, Model 3, the degree of openness interacts positively with spillovers variable (FDI*open) and significantly affects the productivity of domestic manufacturing firms in Ethiopia. This is attributed to presence of export-oriented foreign firms in the manufacturing sector after the government adopts export promotion policy. This creates an opportunity for domestic firms to interact with foreign firms and learn through exporting. By adopting export process of foreign firms, domestic firms will reduce entry cost to international market and improve their respective productive efficiency. Therefore, open trade policy of the country facilitates positive FDI spillovers within the industry. The firm level study by Li et al (2001) confirms that the efficiency of local Chinese firms increases due to the presence of export-oriented FDI firms in the country. The result is also in line with the firm level study by Farole and Winkler (2012) on firms in low and middle-income countries and Temenggung (2007) on Indonesian manufacturing firms. 
Moreover, (Crespo and Fontoura, 2011) reiterated that FDI spillovers are likely to be positive in countries adopting open trade policies and export promotion strategy than import substitution strategy which supports our finding.

According to Jude (2013) horizontal spillovers mainly depends on human capital relative to the vertical transfers. As we can see from the above table, the interaction of human capital with the FDI spillovers variable $\left(F D I^{*} h u m\right)$ ) results in a positive and significant effect on productivity of domestic firms. This is attributed to the rising share of government expenditure on education combined with increasing number of people with completed secondary and tertiary education which, in turn, increases the share of skilled labor in the industry. The presence of better human capital enhances the domestic firms' absorptive capacity and facilitates the intra-industry technology and knowledge transfer in the country.

According to Boly et al (2013) and Farole et al (2014) the demonstration effect on domestic firms highly depends on availability of learning and innovation infrastructure. The finding is also similar with the previous firm level study by Farole and Winkler (2012) and finding by Blalock and Gertler (2009) on Indonesian manufacturing sector. As we can see from the above estimation result both models show that the investment freedom in the country, which measures the ability of firms to move resources freely inside and across the border, also positively interacts with spillovers variable $(F D I * i n v)$ although the effect is not statistically significant.

As far as the control variables are concerned, the sign of the coefficients is in line with our priori expectation except in the case of firm's size. The significance of the control variables is also consistent both in Model 2 and Model 3. The unexpected sign of the size variable might be attributed to the inverse relationship between firm size, measured in total number of employees, and labor productivity, measured using value added per worker. The sign of coefficient of sector level concentration measure (HHI) is positive implying that the degree of competition in manufacturing sector enhances productivity of firms but the effect is not statistically significant. Similarly, the capital intensity of firms positively and significantly affects their respective productivity. Moreover, age of the firms positively and significantly affects firms' productivity. The longer the firm stays in the industry, the higher will be the chance to have better absorptive capacity and reap positive spillovers which enhances productivity. The finding is in line with firm level study by (Sanfilippo and Seric, 2014). 


\section{Conclusions and Policy Implications}

\subsection{Conclusions}

This paper is aimed at analyzing the role of host country characteristics and institutional framework on FDI spillovers in Ethiopia focusing on the manufacturing firms. As far as our knowledge is concerned, this is the first study to analyze the effect of interaction of FDI with mediating factors on productivity of firms in Ethiopia. In this study, we also try to separate the labor mobility channel from the other channels of horizontal spillovers. Moreover, to be more confident about the net spillovers effect of the presence of foreign firms with in the manufacturing industry other observable and unobservable factors affecting productivity of domestic firms were incorporated.We use unbalanced firm level panel data covering the period 2003 to 2010 obtained from CSA in combination with host country factors and institutional framework data obtained from ADI, WDI and Heritage foundation

Both descriptive and econometric analyses are used to address the general as well as specific objectives. The descriptive analysis shows that employment and gross capital formation contribution of FDI has been increasing in the country. Sector wise, manufacturing sector takes largest share during the period under consideration. The largest share of manufacturing sector might be attributed to special tax and non tax related incentive schemes to investors engaged in the sector. Industry wise, labor intensive manufacturing industries contribute more than 90 percent of employment and value added in the sector. However, the sectors' contribution to value added and export is lower relative to agriculture and service sectors in the country as well as the Sub-Saharan Africa average.

For the econometric analysis, panel data econometric analysis with fixed effects estimation technique is used. Accordingly, we estimate the baseline model, the model with control variables and the model incorporating firm and industry specific effects to assess the net spillovers effects of FDI. The estimation result reiterates that the presence of foreign firms positively affects the productivity of domestic firms in horizontal channels other than labor mobility channel. However, the presence of foreign firms results in employee's turnover from domestic to foreign firms which adversely affect the productivity of domestic firms. The labor turnover effect will not reverse even in one year. The empirical estimation result of the interaction term also shows that the labor mobility from domestic to foreign firms might also be attributed to the loose labor market regulation of the country. 
On the other hand, the estimation result reiterated that the country's financial sector improvement in terms of banking efficiency and growing human capital stock positively mediates the spillovers effect from FDI. Moreover, export-oriented trade policy of the country enhances the productivity of domestic firms as it facilitates learning through exporting. Similarly, the investment freedom positively moderates the spillovers effect of FDI although it is not significant. The effect of sectoral concentration on productivity of firms is also positive but insignificant.

As far as the control variables are concerned, the capital intensity and age of the domestic firms positively and significantly affects the productivity of domestic firms. We find unexpected sign for the variable firm size which might be attributed to the inverse relationship between our productivity and size measures in our model. 


\subsection{Policy Implications}

The spillovers effect of FDI does not accrue automatically with the presence of foreign firms. There are various mediating factors affecting the knowledge and technology transfer from foreign to domestic firms one of which is host country factors and institutional framework. The host country factors and institutions requires due attention as it directly affects the absorptive capacity of domestic firms as well as spillovers potential of foreign firms.

Overall the findings suggest that trade openness, growing human capital stock and financial sector development positively mediates the knowledge and technology transfer. On the other hand, labor market regulation of the country facilitates the adverse effect of labor mobility on productivity of domestic firms. This do have the following policy implications:

Labor mobility from domestic to foreign firms will hamper localization of management and technical staffs and reduces the dynamic gains from FDI. Therefore, formulating minimum

wage legislation and supportting research and training programmes of domestic firms helps to maintain and attract skilled workers and enhance their absorptive capacity.

The government should promote FDI-local indsutry linkages through creating industrial parks, implementing minimum local content requirments as well as facilitating joint research and workers training programmes.

The country's development policy at large should integrate spillovers as part of wider industrial development policy to facilitate technology and knowledge transfers between domestic and foreign firms.

Creating reliable regulatory starndards and providing adequate infrastructure can play constructive role in improving absorptive capacity of domestic firms as well as spillovers

potential of foreign firms .

Further liberalization of trade increases existing firms participation in the global value chains and creates an opportunity for the local firms to benefit more from technology and

knowledge diffusion

Supporting entry of new firms through supply side capacity building and improving the quality of education enables domestic firms to maximize the productivity gains from foreign firm presence. 
The existing financial sector development positively mediates the spillovers effect of FDI in the manufacturing industry. This calls for further liberalization of banks and financial markets which reduce the cost of borrowing and the risk of imitating technology as well as training of workers. 


\section{References}

Abeba, T.(2014) "FDI and the Spillovers Effect Analaysis: The Case of Ethiopia", IES Working Paper, Charles University in Prague, Institute of Economic Studies.

Abraham,F.,Konings, J. andSlootmaekers,V.(2010) "FDI Spillovers in Chinese Manufactring Sector: Evidence of Firm Hetrogeniety” Economies of Transition No. 18, PP. 143-82.

Agarwal,N. Milner,C. and Riano,A.(2011) “Credit Constraints and FDI Spillovers in China”, China and World Economy Research Series No.21/2011, University of Nottingham.

Alfaro,L., Chanda ,A., Kalemli-Ozcan,S. and Sayek,S.(2004) "FDI and Economic Growth: The Role of Local Financial Markets”, Journal of International Economics, 64, 89-112.

Amendolagine,V., Boly,A., Coniglio,N. and Prota,F.(2013) "FDI and Local Linkags in Developing Countries: Evidence from Sub-Saharan Afrcia”, Development Policy, Statistics and Research Branch Working Paper No7.2012, UNIDO, Austria, Vienna.

Amighini, A. and Sanfilippo,M.(2014) "Impact of South-South FDI and Trade on Export Up grading of African Economies, World Development, 64:1-17.

Asiedu, E.(2005) "Foreign Direct Investment in Africa: The Role of Natural Resources, Market Size, Government Policy, Institutions and Political Instability”, UN-WIDER Research Paper, No.2005/24.

Balsvik, R.(2011) "Is Labor Mobility Channel for Spillovers from Multinationals? Evidence from Norweigan Manufacturing”, Review of Economics and Statistics 93(1): 285-97.

Baltagi .B. (2005) "Econometric Analysis of Panel Data", 3 rd edition, John Wiley \& Sons Ltd, West Sussex, England.

Bhagwati, J.(1978). “Anatomy and Consequences of Exchange Control Regimes", New York: Balinger Publishing.

Blalock,G.and Gertler, P.J.(2009) "How Firm Capabilities Affect Who Benefiits from Foreign Technology", Journal of Development Economics, 90(2):192-199. 
Boly,A., Coniglio,N.,Prota,F.and Seric,A.(2013) "Which Domestic Firms Benefit from FDI? Evidence from Selected African Countries”, Development Policy, Statistics and Research Branch Working paper 8/2012. UNIDO, Austria, Vienna.

Clark,P.C.(2013) “The Effects of Multicollinearity in Multilevel Models”, Unpublished Doctoral Dissertation, Wright State University. Accessed on https://etd.ohiolink.edu/!etd.send_file?accession=wright1375956788\&disposition=inline (last consulted $: 12^{\text {th }}$ August,2015).

Costa da Massingue,C.(2012) “Are There Spillover Effects from Foreign Direct Investment in Sub-Saharan Africa? Asessing the Linkage Effects in Mozambique", Unpublished Masters Dissertation, University of London.

Crespo,N. and Fontoura,M.(2007) "Determinants Factors of FDI Spillovers-What Do We Really Know?” World Development 35(3):410-25.

CSA (2011/12) “Central Statistics Authority Annual Report for the year 2011/12", Addis Ababa, Ethiopia.

Cuervo-Cazurra,A. and Genc,M.(2008) "Transforming Disadvantages in to Advantages: Developing-Country MNEs in Least Developed Countries", Journal of International Business Studies 39(6):957-79.

Demeke, A., Dereje, T. and Han, D.G.(2012) "Determinants of Foreign Direct Investment: Reflections from Ethiopia”, Social and Basic Sciences Research Review, 2(2):85-95.

EIA (2012) “Ethiopian Investment Agency Annual Report”, Addis Ababa, Ethiopia EIA (2010) “Ethiopia Investment Guide” Addis Ababa, Ethiopia Ermias, S. (2013) "The Spillovers Effects of Foreign Direct Investment Inflow on Productivity of Domestic Firms: A Case of Ethiopian Manufacturing Firms”, Unpublished Masters Dissertation, Institute of Social Studies, The Hague, Netherlands. Accessed on http://thesis.eur.n1/pub/15425/ (last consulted: $18^{\text {th }}$ July, 2015).

Farole,T., Staritz, C.and Winkler,D.(2014) "Making Foreign Direct Investment Work for Sub-Saharan Africa: Local Spilovers and Competitivness in Global Value”, the World Bank, Washington, D.C. 
Farole,T.and Winkler,D.(2012) "Foreign Firm Characterstics, Absorpitive Capacity and the Institutional Framework:The Role of Mediating Factors for FDI Spillovers in Low and Middle-Income Countries”, Policy Research Working Paper No. 6265, World Bank, Washington, DC.

Fosfuri,A.,Motta, M. and Ronde,T.(2001)“Foreign Direct Investment and Spillovers Through Workers’ Mobility”,Journal of International Economics ,53(1):205-22.

Frederick,S. and Staritz,C.(2012) "Developments in the Global Apparel Industry after the MFA Phase out", in Lopez-Acevodo,G. and Robertson,R.(eds.) Sewing Success? Employment, Wages and Poverty following the End of the Multifiber Arrangement, PP.41, World Bank, Washington DC.

Girma,S.(2005) "Absorptive Capacity and Productivity Spillovers from FDI: A Threshold Regression Anaysis", Oxford Bulletin of Economics and Statistics 67(3): 281-306.

Gorg, H. and Strobl,E.(2005) “ Spillovers from Foreign Firms through Workers Mobility: An Emperical Investigation”, Scandinavian Journal of Economics, 107, 693-709.

Greene, W.H.(2003) "Econometric Analysis", 5 ${ }^{\text {th }}$ edition. Pearson Education, Inc. Delhi, India.

Greenway, D., Sousa,N. and Wakelin,K.(2004) "Do Domestic Firms Learn to Export from Multinationals?" European Journal of Polictical Economy 20(4): 1027-43.

Hale ,G.and long,C.(2011) “Did FDI Put an Upward Pressure on Wage in China?”, IMF Economic Review, No.59: PP.404-30.

Havranek,T. and Irsova.Z.(2011) "Estimating Vertical Spillovers from FDI: Why Results Vary and What the True Effect Is", Journal of International Economics, No.85., PP.234-44.

Henok, G.(2014) "Determinants and Impediments of FDI Inflow in Ethiopia: A Firm Level Investigation “, MPRA Paper No.55955.

Hermes,N. and Lensink, R.(2003) "Foreign Direct Investment, Financial Development and Economic Growth”, Journal of Development Studies, 40(1), 142-163. 
Hoekman,B. and Javorcik,B.(2006) "Lessons from Emperical Research on Technology Diffusion Through Trade and Foreign Direct Investment", In Global Integration and Technology Transfer, World Bank, Washington, DC.

Javorcik,B.(2004) "Does Foreign Direct Investment Increase the Productivity of Domestic Firms? In Search of Spillovers through Backward Linkages", American Economic Review 94(3): 605-27.

Javorcik, B.(2004b)"The Composition of Foreign Direct Investment and Protection of Intellectual Property Rights: Evidence from Transition Economies", European Economic Review 48(1):39-62.

Javorcik,B.(2008) "Can Survey Evidence Shed Light on Spillovers from Foreign Direct Investment ?" World Bank Research Observer, 23(2):139-59.

Jordaan, J.(2011) "Local Sourcing and Technology Spillovers to Mexican Suppliers: How Important Are FDI and Supplier Characterstics?" Growth and Change 42(3): 287-319.

Kohpaiboon,A.(2009) "Vertical and Horizontal FDI Technology Spillovers: Evidence from Thai Manufacturing", in Corbett,J.and S.Umezaki (eds.) Deepening East Asian Economic Integration. ERIA Research Project Report 2008-1,PP.314-355.Jakarta:ERIA.

Kokko,A., Zejan,M. and Tansini,R.(2001) "Trade Regimes and Spillover Effects of FDI: Evidence from Uruguay", Weltwirtschaftliches Archiv,137(1), 124-149.

Lesher,M. and Miroudot,S.(2008) "FDI Spillovers and Their Interrelationships with Trade", OECD Trade Policy Working Paper No.80, Organization for Economic Co-opration and Development(OECD), Paris.

Li,X., Liu,X. and Parker,D.(2001) “ Foreign Direct Investment and Productivity Spillovers in the Chinese Manufacturing Sector”, Economic Systems 25(4): 305-21.

Lipsey,R. and Sjoholm,F.(2004) "Foreign Direct Investment, Education and Wages in Indonesian Manufacturing ”, Journal of Development Economics ,73, 415-422.

Lipsey,R. and Sjoholm,F.(2005) "The Impact of Inward FDI on Host Countries:Why Such Different Answers?”, in Moran,T.,E. Graham, and M.Blomstrom(eds.) Does Foreign Direct Investment Promote Development?, pp.23-43, Washington,D.C.: Institute for International Economics and Center for Global Development. 
Melaku,T.A.(2013) "Total Factor Productivity and Technical Effeciency in the Ethiopia Manufacturing sector”, EDRI Working Paper No.10, Addis Ababa, Ethiopia.

Merlevede,B. and Schoors,K.(2007) "FDI and the Consequences: Towards More Complete Capture of Spillover Effects," William Davidson Institute Working Papers Series No. 886, William Davidson Institute at University of Michigan.

MOFED(2011) “Annual Report on Macroeocnomic Development”, Addis Ababa, Ethiopia.

MOFED(2014) “Growth and Transformation Plan Annual Progress Report for 2012/13”, Addis Ababa, Ethiopia.

Nicolini,M.and Resmini,L.(2010) “FDI Spillovers in New EU Member States," Economics of Transition, 18(3): 487-511.

Ofosu,A. and Waldkirch,A.(2008) "Foreign Presence,Spillovers and Productivity: Evidence from Ghana", MPRA Paper No.8577.

Perez-Vilar,L. and Seric,A.(2014) "Multinationals in Sub-Saharan Africa: Domestic Linkages and Institutional Distance", Kiel Working Papers No.1893, Kiel Institute for the World Economy,Germany.

Rao,K.R. and Tesfahunegn,S.Z.(2015)"Performance Measurement of Manufacturing Industries in Ethiopia-An Analytical Study", Journal of Poverty, Investment and Development Vol.7, No.2422.

Sanfilippo,M. and Seric,A.(2014) "Spillovers form Agglomerations and Inward FDI: A Multilevel Analysis on Sub-Saharan African Firms', Europenan University Institute and United Nations Industrial Organizations.

Sheferaw and Tadele (2015) "Economic Growth and Employment Patterns, Dominant Sector, and Firm Profiles in Ethiopia: Opportunities, Challenges and Prospects", R4D Working paper 2015/2, Swiss Programme for Research on Global Issues for Development.

Sisay,S.(2008) "The Nexus Between FDI and Total Factor Productivity Growth in SubSaharan Africa", MPRA Paper No.31067.

Smeets,R.(2011) "Collecting the Pieces of the FDI Knowledge Spillovers Puzzle”, World Bank Research observer, 23(2):107-38. 
Stancik,J (2009) “FDI Spillovers in the Czech Republic: Takeovers Vs.Greenfields”, Economic papers, No.369, European Economic Commission.

Temenggung,D.(2007) "Productivity Spillovers from Foreign Direct Investment:Indonesian Manufacturing Industry’s Experience 1975-2000”, Australian National University, Canberra, Australia.

Torres-Reyna, O.(2008) "Panel Data Analysis: Fixed and Random Effects", Princeton University Accessed on http://www.princeton.edu/ otorres/Panel101.pd (last consulted, $25^{\text {th }}$ July,2015).

Tytell, I. and Yudaeva, K.(2007) "The Role of FDI in Eastern Europe and New Independent States: New Channels for the Spillover Effect”, in Liebscher,K.,J.Christl,P. Mooslechner, and D.Ritzberger-Grunwald (eds.) Foreign Direct Investment in Europe: A changing landscape, PP.76-78. ,Cheltenham, U.K. Edward Elgar.

UNIDO(2012) “Africa Investors Report 2012: Towards Evidence-Based Investment Promotion Stratagies", United Nations Industrial Development Organization, Vienna.

UNIDO(2014) "The International Yearbook of Industrial Statistics", United Nations Industrial Development Organization, Vienna.

Verbeek, M. (2000) “A Guide to Modern Econometrics”, John Wiley and Sons, Ltd. USA.

Williams,R.(2015)“Multicollinearity”,University of Notre Dame. Accessed on https://www3.nd.edu/ rwilliam/stats2/111.pdf (last consulted: $12^{\text {th }}$ August,2015).

World Bank(2012) "Chinese Foreign Direct Investment in Ethiopia”, A World Bank Survey No.74384, World Bank.

World Bank (2013) "Ease of Doing Business in Ethiopia", World Bank Group, Washington DC. Accessed on http://www.doingbusiness.org/data/exploreeconomies/ethiopia(last condulted $5^{\text {th }}$ August,2015).

Zhou,Y.(2014) "FDI and Technical Effeciency in Manufacturing Firms: A Stochastic Frontier Approach”, Master's Thesis, Department of Economics, University of San Francisco. 


\section{Appendices}

\section{Annex 1: Descriptive Statistics}

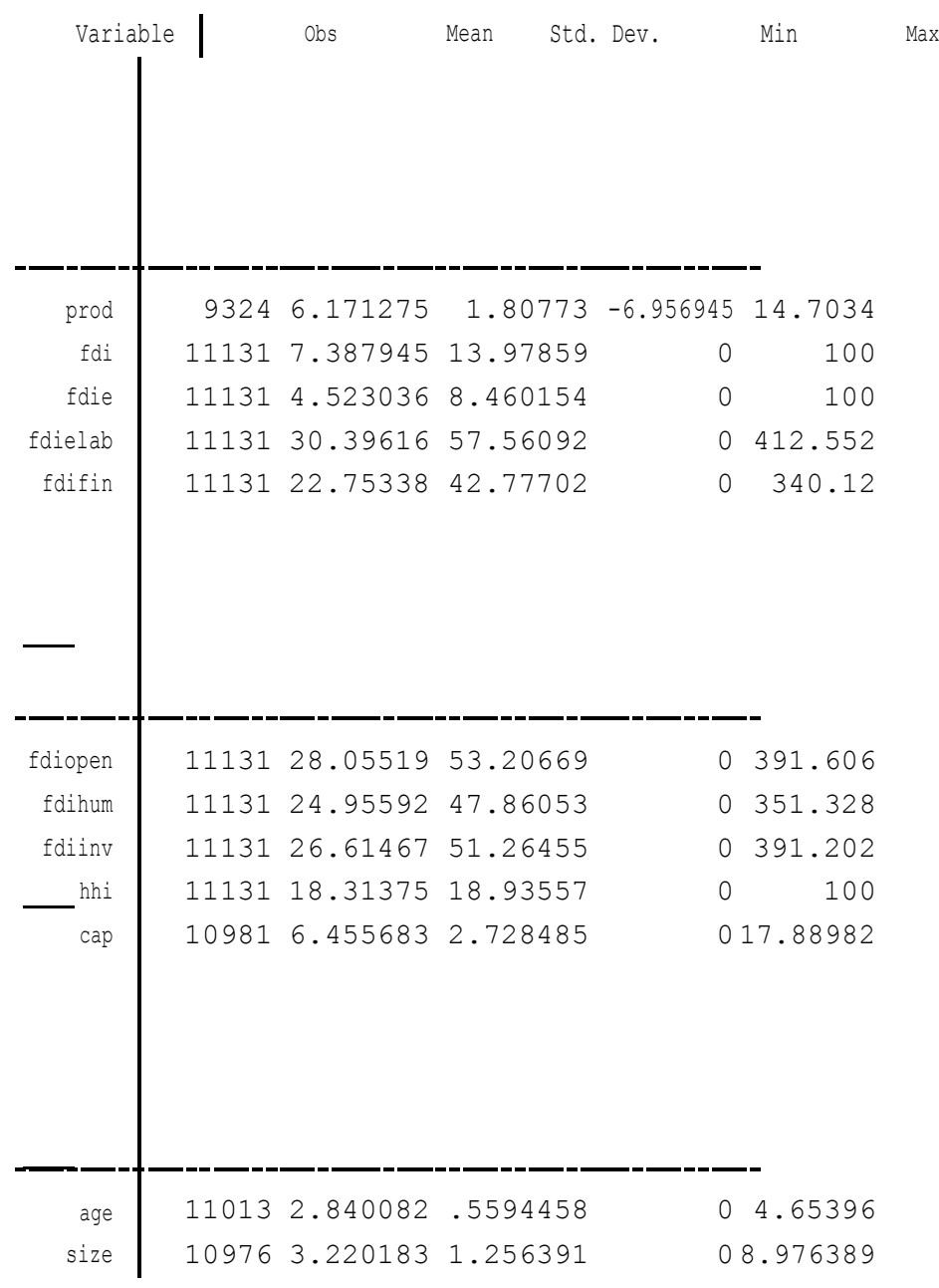

Note: prod, cap, age and size variables are taken in their log transformed form after Conducting normal distribution test

\section{Annex 2: Hausman Specification Test}

\begin{tabular}{|c|c|c|c|}
\hline & $\begin{array}{rr}\text { (b) } & \text { (B) } \\
\mathrm{fe} & \mathrm{re}\end{array}$ & $\begin{array}{c}(b-B) \\
\text { Difference }\end{array}$ & $\begin{array}{c}\operatorname{sqrt}\left(\operatorname{diag}\left(V_{-} b-V_{-} B\right)\right) \\
\text { S.E. }\end{array}$ \\
\hline fdi & $-2324.233-1786.545$ & -537.6881 & 743.953 \\
\hline fdie & $63.96574 \quad 29.01327$ & 34.95247 & 83.29886 \\
\hline fdielab & $-2.144766-.1439465$ & -2.000819 & 1.367313 \\
\hline fdifin & $-1452.675-1067.428$ & -385.247 & 163.4962 \\
\hline fdiopen & 3343.4392418 .179 & 925.2606 & 202.07 \\
\hline fdihum & $-1238.137-778.7148$ & -459.4224 & 163.3857 \\
\hline fdinv & $-440.5409-385.6498$ & -54.89108 & 38.17762 \\
\hline hhi & $36.35419 \quad 66.6037$ & -30.24951 & 8.187162 \\
\hline cap & .000278 .0005877 & -.0003097 & .0001601 \\
\hline age & $-102.9602-105.6332$ & 2.673044 & 23.09402 \\
\hline size & $-7.00735-5.272279$ & -1.73507 & 1.194738 \\
\hline
\end{tabular}


= inconsistent under Ha, efficient under Ho; obtained from xtreg

Test: Ho: difference in coefficients not systematic

$$
\begin{aligned}
\operatorname{chi} 2(10) & =(\mathrm{b}-\mathrm{B}) \cdot\left[\left(\mathrm{V}_{-} \mathrm{b}-\mathrm{V}_{-} \mathrm{B}\right) \wedge(-1)\right](\mathrm{b}-\mathrm{B}) \\
= & 55.38 \\
\text { Prob }>\operatorname{chi} 2= & 0.0000
\end{aligned}
$$




\section{Annex 3: Test for Hetroskedasticity}

- xttest3

Modified Wald test for groupwise heteroskedasticity

in fixed effect regression model

HO: sigma(i)^2 = sigma^2 for all i

$\operatorname{chi2}(4459)=4.6 \mathrm{e}+40$

Prob $>$ chi2 $=0.0000$

\section{Annex 4: Test for Autocorrelation}

- xtserial prod fdi fdie fdielab fdifin fdiopen fdihum fdiinv hhi cap age size

Wooldridge test for autocorrelation in panel data

HO: no first order autocorrelation

$\mathrm{F}(1,1086)=0.696$

Prob $>\mathrm{F}=0.4043$

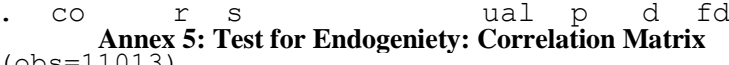
(obs=11013)

\begin{tabular}{|c|c|c|c|c|c|c|}
\hline & residual & prod & fdi & fdie & fdielab & fdifi \\
\hline & -ーーーーーーーー & & & & & \\
\hline residual & 1.0000 & & & & & \\
\hline prod & 0.0749 & 1.0000 & & & & \\
\hline fdi & 0.1615 & 0.0251 & 1.0000 & & & \\
\hline fdie & 0.0354 & 0.0319 & 0.2322 & 1.0000 & & \\
\hline fdielab & 0.0427 & 0.0328 & 0.2300 & 0.9947 & 1.0000 & \\
\hline fdifin & 0.1514 & 0.0238 & 0.9985 & 0.2382 & 0.2352 & 1.000 \\
\hline fdiopen & 0.1707 & 0.0255 & 0.9998 & 0.2328 & 0.2308 & 0.998 \\
\hline fdihum & 0.1732 & 0.0264 & 0.9992 & 0.2274 & 0.2260 & 0.995 \\
\hline fdiinv & 0.1045 & 0.0196 & 0.9956 & 0.2329 & 0.2310 & 0.995 \\
\hline hhi & 0.3146 & 0.0426 & 0.0232 & 0.0518 & 0.0505 & 0.031 \\
\hline cap & 0.2684 & 0.0364 & 0.0356 & 0.0395 & 0.0407 & 0.033 \\
\hline age & -0.4320 & -0.0241 & 0.0422 & 0.0612 & 0.0557 & 0.044 \\
\hline size & -0.4340 & -0.0105 & 0.0191 & 0.0956 & 0.0937 & 0.023 \\
\hline
\end{tabular}




\section{Annex 6: Test for collinearity}

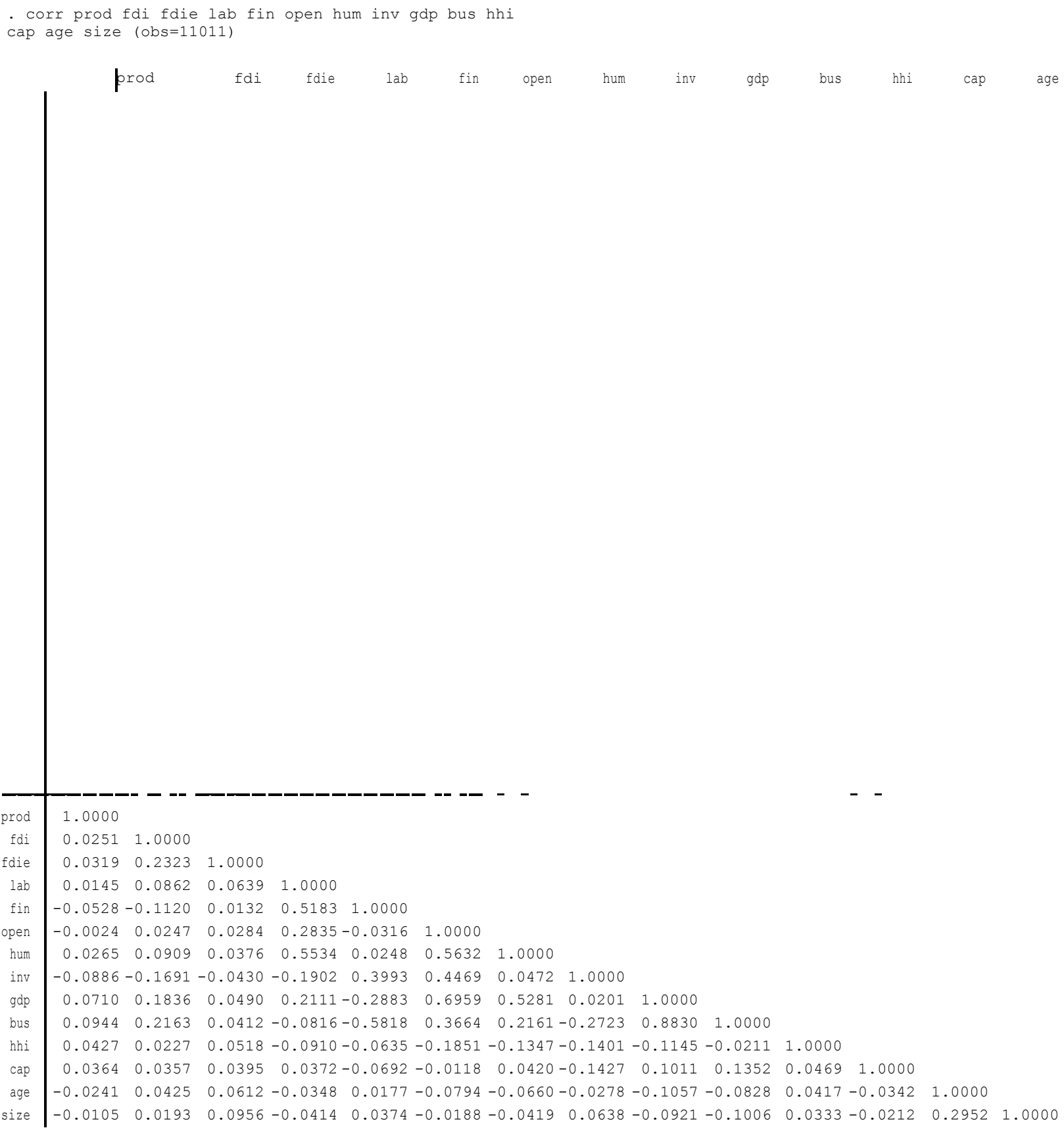

\section{Annex 7: Estimation results of baseline model and the model incorporating control variables}

\begin{tabular}{|c|c|c|}
\hline Variable & model1 & Model2 \\
\hline fdi & $4.8836441 * * *$ & $3.5016887 * \star *$ \\
\hline fdie & -.00173489 & -.00222645 \\
\hline fdielab & $-1.4285433 * * *$ & $\star-1.0062534 * * *$ \\
\hline fdifin & .01140829 & $.06027988 * * *$ \\
\hline fdiopen & $.19133369 * * *$ & .01236974 \\
\hline fdihum & $.10521855 * * *$ & 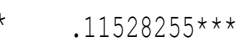 \\
\hline
\end{tabular}




\begin{tabular}{|c|c|c|}
\hline fdiinv & $-.03336784 * \star *$ & .00323317 \\
\hline hhi & & .00126004 \\
\hline cap & & $.19266421 * \star \star$ \\
\hline age & & $.25833521 * * *$ \\
\hline size & & $-.35612825 * * *$ \\
\hline _cons & $6.113139 * * *$ & $5.321836 * \star \star *$ \\
\hline N & 9324 & 8994 \\
\hline r2 & .04263218 & .16158511 \\
\hline r2_a & .04191282 & .16055832 \\
\hline
\end{tabular}

legend: * $\mathrm{p}<0.05 ; * \star \mathrm{p}<0.01 ; * \star * \mathrm{p}<0.001$ 


\section{Annex 8: Test for joint Significance}

- test hhi age cap size
(1) hhi $=0$
(2) age $=0$
(3) cap $=0$
(4) size $=0$

$$
\begin{aligned}
F(4,3814) & =83.13 \\
\text { Prob }>F & =0.0000
\end{aligned}
$$

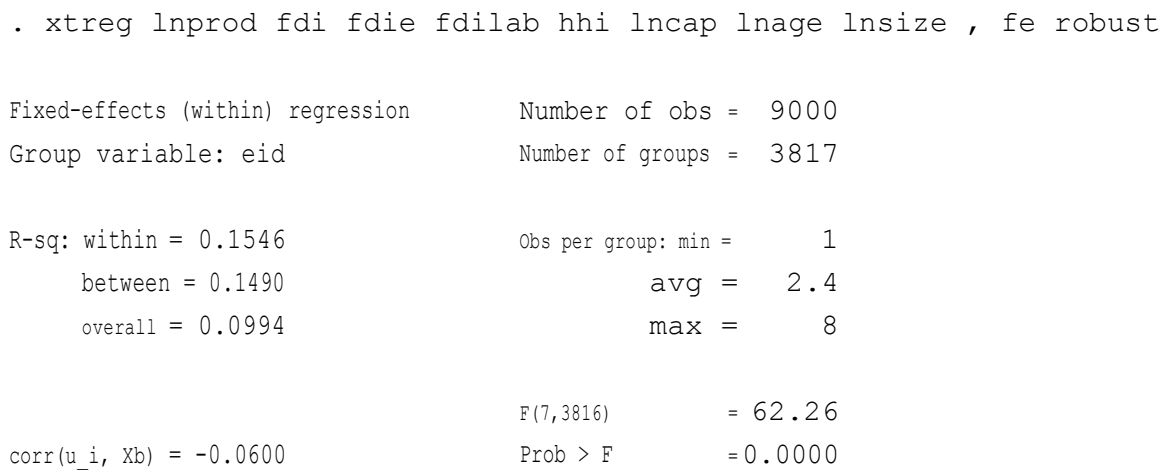

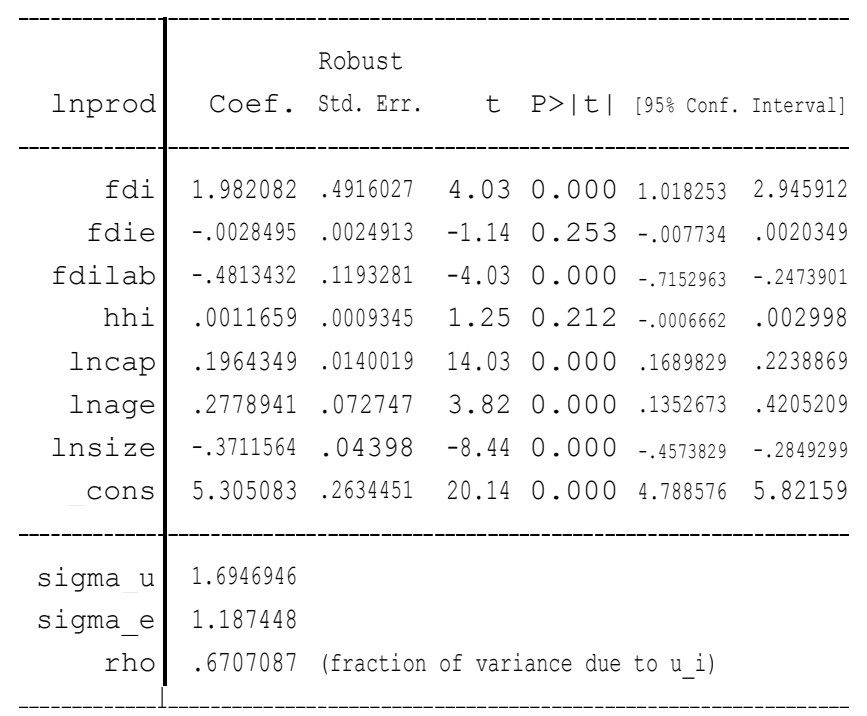




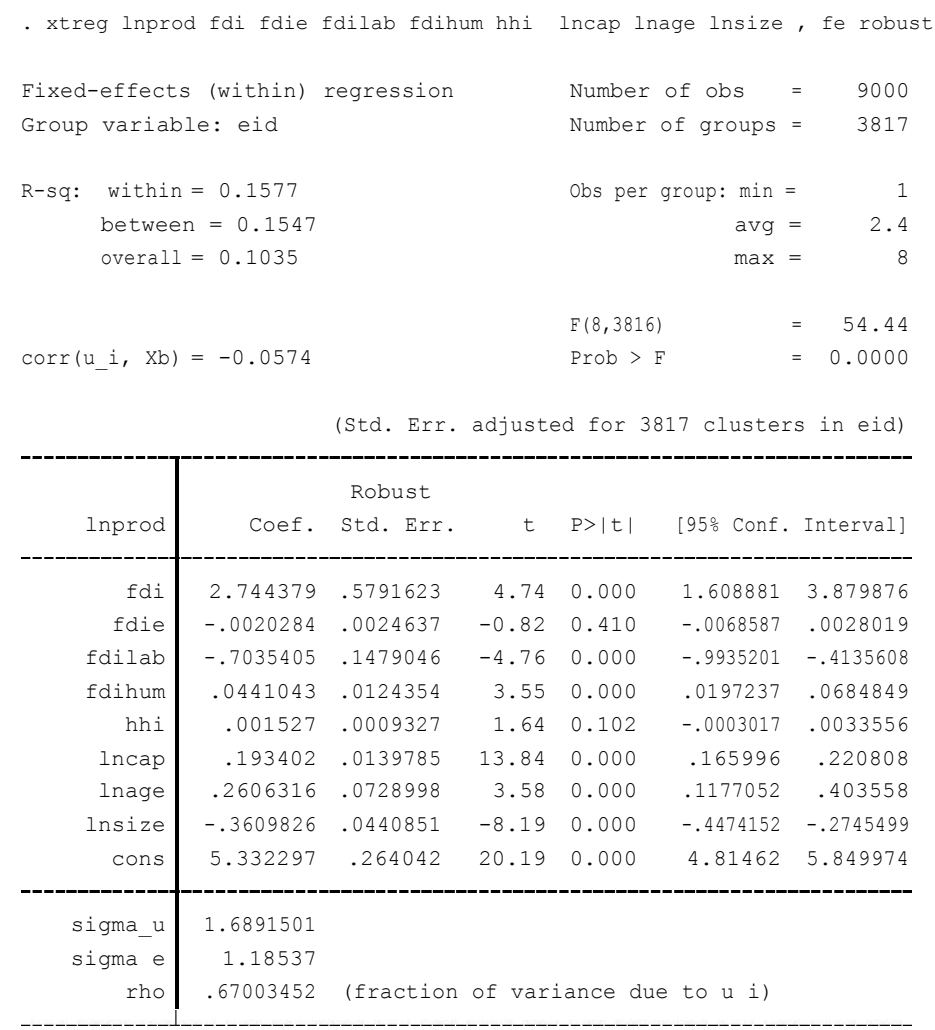

. xtreg lnprod fdi fdie fdilab fdihum fdiopen hhi lncap lnage lnsize, fe robust

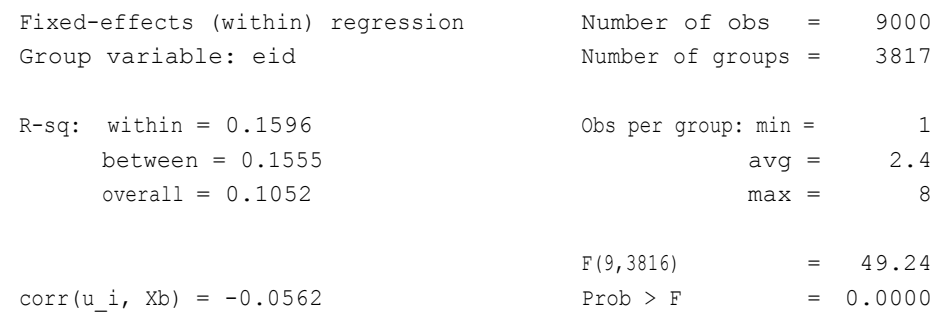

(Std. Err. adjusted for 3817 clusters in eid)

\begin{tabular}{|c|c|c|c|c|c|c|}
\hline Inprod & Coef. & $\begin{array}{l}\text { Robust } \\
\text { Std. Err. }\end{array}$ & t & $P>|t|$ & [95\% Conf. & Interval] \\
\hline fdi & 3.896239 & .7508362 & 5.19 & 0.000 & 2.424161 & 5.368318 \\
\hline fdie & -.0020644 & .0024571 & -0.84 & 0.401 & -.0068817 & .002753 \\
\hline fdilab & -1.076958 & .2126894 & -5.06 & 0.000 & -1.493954 & -.6599625 \\
\hline fdihum & .0601589 & .0152887 & 3.93 & 0.000 & .0301841 & .0901338 \\
\hline fdiopen & .0868349 & .030352 & 2.86 & 0.004 & .0273272 & .1463426 \\
\hline hhi & .0012875 & .0009305 & 1.38 & 0.167 & -.0005369 & .0031119 \\
\hline Incap & .1873079 & .0141905 & 13.20 & 0.000 & .1594863 & .2151296 \\
\hline lnage & .2639857 & .0730672 & 3.61 & 0.000 & .1207311 & .4072403 \\
\hline Insize & -.3545317 & .0440585 & -8.05 & 0.000 & -.4409121 & -.2681512 \\
\hline _cons & 5.341333 & .2640117 & 20.23 & 0.000 & 4.823715 & 5.858951 \\
\hline sigma_u & 1.688037 & & & & & \\
\hline sigma_e & 1.1841709 & & & & & \\
\hline rho & .67019051 & (fraction & of va & ance $d u$ & to u_i) & \\
\hline
\end{tabular}




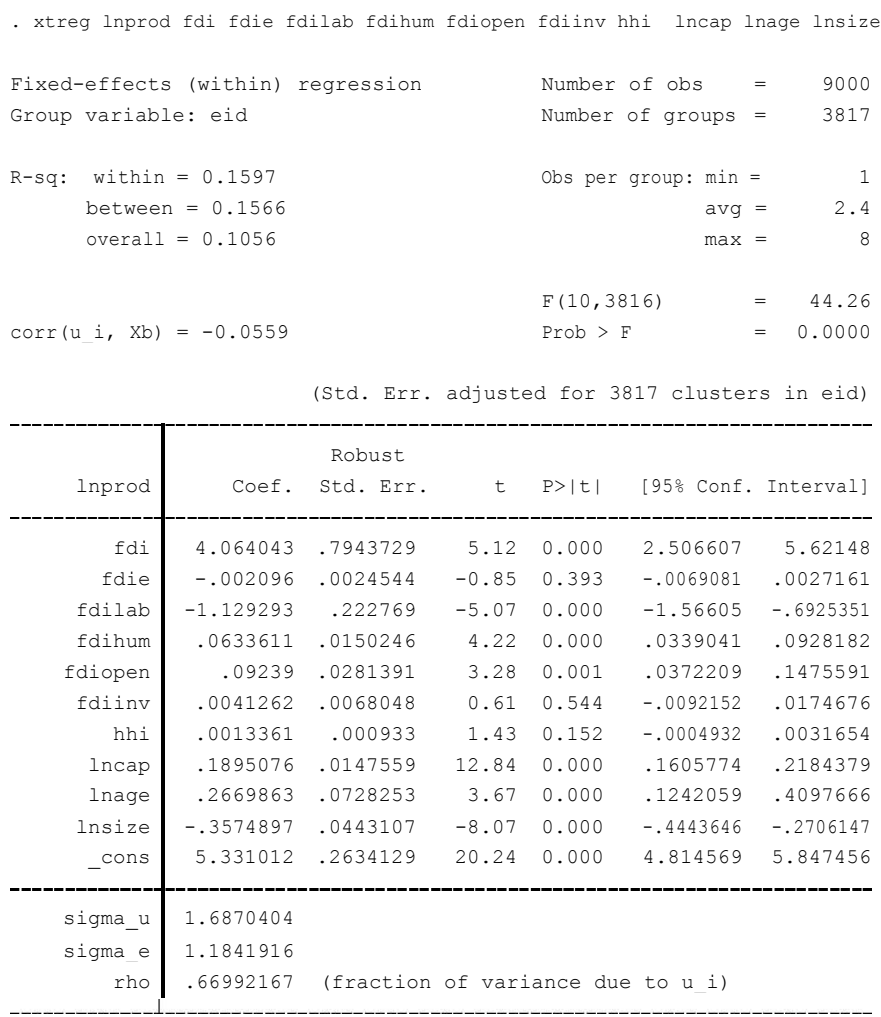

- xtreg Inprod fdi fdie fdilab fdihum fdiopen fdiinv fdifin hhi lncap lnage Insize, fe robust

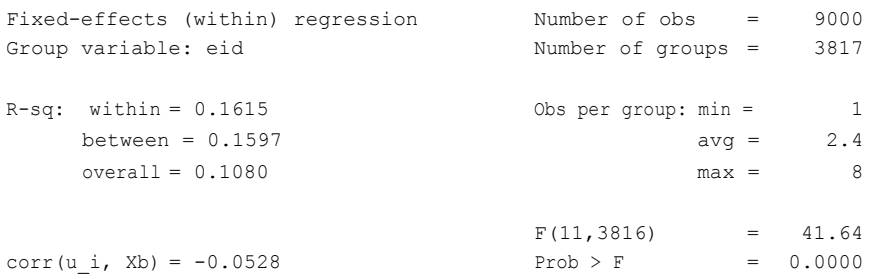

(Std. Err. adjusted for 3817 clusters in eid)

\begin{tabular}{|c|c|c|c|c|c|c|}
\hline Inprod & Coef. & $\begin{array}{l}\text { Robust } \\
\text { Std. Err. }\end{array}$ & t & $P>|t|$ & [95\% Conf. & Interval] \\
\hline fdi & 3.497029 & .72897 & 4.80 & 0.000 & 2.06782 & 4.926237 \\
\hline fdie & -.0022894 & .0024327 & -0.94 & 0.347 & -.007059 & .0024802 \\
\hline fdilab & -1.004926 & .2088092 & -4.81 & 0.000 & -1.414314 & -.5955373 \\
\hline fdihum & .1150702 & .0247193 & 4.66 & 0.000 & .0666059 & .1635344 \\
\hline fdiopen & .0123418 & .0373149 & 0.33 & 0.741 & -.0608173 & .0855009 \\
\hline fdiinv & .0033008 & .0067448 & 0.49 & 0.625 & -.0099229 & .0165246 \\
\hline fdifin & .0602054 & .0175841 & 3.42 & 0.001 & .0257302 & .0946806 \\
\hline hhi & .0012431 & .0009213 & 1.35 & 0.177 & -.0005633 & .0030495 \\
\hline Incap & .1927526 & .0148684 & 12.96 & 0.000 & .1636017 & .2219034 \\
\hline Inage & .2615158 & .0728787 & 3.59 & 0.000 & .1186308 & .4044008 \\
\hline lnsize & -.3582577 & .0443048 & -8.09 & 0.000 & -.4451211 & -.2713943 \\
\hline _cons & 5.320936 & .2628485 & 20.24 & 0.000 & 4.805599 & 5.836273 \\
\hline sigma_u & 1.6844339 & & & & & \\
\hline sigma_e & 1.183029 & & & & & \\
\hline rho & .66967223 & (fraction & of var & ince due & to $u_{-}$i) & \\
\hline
\end{tabular}


Annex 10: Testing the significance of industry and firm fixed effects

\begin{tabular}{|c|c|c|c|c|}
\hline$(1)$ & 1514.industry & $=$ & 0 & \\
\hline$(2)$ & 1520. industry & $=$ & 0 & \\
\hline$(3)$ & 1531.industry & $=$ & 0 & \\
\hline$(4)$ & 1533. industry & $=$ & 0 & \\
\hline$(5)$ & 1541.industry & $=$ & 0 & \\
\hline$(6)$ & 1542. industry & $=$ & 0 & \\
\hline$(7)$ & 1544.industry & $=$ & 0 & \\
\hline$(8)$ & 1549.industry & $=$ & 0 & \\
\hline ( 9) & 1551.industry & $=$ & 0 & \\
\hline$(10)$ & 1552. industry & $=$ & 0 & \\
\hline$(11)$ & 1553. industry & $=$ & 0 & \\
\hline (12) & 1554.industry & $=$ & 0 & \\
\hline (13) & 1600.industry & $=$ & 0 & \\
\hline$(14)$ & 1710.industry & $=$ & 0 & \\
\hline$(15)$ & 1711.industry & $=$ & 0 & \\
\hline$(16)$ & 1720.industry & $=$ & 0 & \\
\hline$(17)$ & 1723.industry & $=$ & 0 & \\
\hline (18) & 1730.industry & $=$ & 0 & \\
\hline (19) & 1810.industry & $=$ & 0 & \\
\hline$(20)$ & 1910.industry & $=$ & 0 & \\
\hline$(21)$ & 1920.industry & $=$ & 0 & \\
\hline$(22)$ & 2000.industry & $=$ & 0 & \\
\hline$(23)$ & 2100.industry & $=$ & 0 & \\
\hline$(24)$ & 2200.industry & $=$ & 0 & \\
\hline$(25)$ & 2220.industry & $=$ & 0 & \\
\hline$(26)$ & 2411.industry & $=$ & 0 & \\
\hline$(27)$ & 2421.industry & $=$ & 0 & \\
\hline$(28)$ & 2422. industry & $=$ & 0 & \\
\hline (29) & 2423. industry & $=$ & 0 & \\
\hline$(30)$ & 2424.industry & $=$ & 0 & \\
\hline (31) & 2429. industry & $=$ & 0 & \\
\hline$(32)$ & 2510.industry & $=$ & 0 & \\
\hline (33) & 2520.industry & $=$ & 0 & \\
\hline$(34)$ & 2610.industry & $=$ & 0 & \\
\hline (35) & 2693.industry & $=$ & 0 & \\
\hline$(36)$ & 2694.industry & $=$ & 0 & \\
\hline$(37)$ & 2695. industry & $=$ & 0 & \\
\hline$(38)$ & 2699.industry & $=$ & 0 & \\
\hline (39) & 2710.industry & $=$ & 0 & \\
\hline$(40)$ & 2720.industry & $=$ & 0 & \\
\hline$(41)$ & 2811.industry & $=$ & 0 & \\
\hline$(42)$ & 2892. industry & $=$ & 0 & \\
\hline$(43)$ & 2893. industry & $=$ & 0 & \\
\hline$(44)$ & 2899.industry & $=$ & 0 & \\
\hline$(45)$ & 2914.industry & $=$ & 0 & \\
\hline$(46)$ & 2924.industry & $=$ & 0 & \\
\hline$(47)$ & 2925. industry & $=$ & 0 & \\
\hline$(48)$ & 2930.industry & $=$ & 0 & \\
\hline$(49)$ & 3000. industry & $=$ & 0 & \\
\hline$(50)$ & 3130.industry & $=$ & 0 & \\
\hline$(51)$ & 3140. industry & $=$ & 0 & \\
\hline$(52)$ & 3410. industry & $=$ & 0 & \\
\hline (53) & 3420.industry & $=$ & 0 & \\
\hline$(54)$ & 3430.industry & $=$ & 0 & \\
\hline \multirow[t]{3}{*}{ (55) } & 3610.industry & $=$ & 0 & \\
\hline & $\operatorname{chi2}(55)$ & $=$ & & 943.85 \\
\hline & Prob > chi2 & $=$ & & 0.0000 \\
\hline
\end{tabular}


Note: We capture the firm fixed effects by incorporating absorb (firm) option in our model estimation as it is it is too large to display the test result for 11131 observations in STATA. The significance of the firm fixed effects is checked by estimating the model with and without including the absorb (firm) option. According to Torres-Reyan 2010) using either of the following two commands will give us the same result:

- areg prod fdi fdie fdielab fdifin fdiopen fdihum fdiinv hhi cap age size i.industry ,absorb(firm)

OR

. xi: regress prod fdi fdie fdielab fdifin fdiopen fdihum fdiinv hhi cap age size i.industry i.firm

\section{Annex 11: Estimation results with and without incorporating industry and firm fixed effects}

- xtreg prod fdi fdie fdilab fdifin fdiopen fdihum fdiinv hhi age cap size, fe robust
. areg prod fdi fdie fdilab fdifin fdiopen fdihum fdiinv hhi age cap size i.industry, absorb(firm) robust

\begin{tabular}{|c|c|c|}
\hline Variable & model2 & model 3 \\
\hline fdi & $3.5016887 * \star \star *$ & $5.3646978 * \star \star *$ \\
\hline fdie & -.00222645 & $-.00547532 *$ \\
\hline fdielab & $-1.0062534 * \star \star$ & $-1.5392134 * \star \star$ \\
\hline fdifin & $.06027988 * \star \star$ & $.04750662 *$ \\
\hline fdiopen & .01236974 & $.1048222 *$ \\
\hline fdihum & $.11528255 * \star \star$ & $.1127907 \star \star \star$ \\
\hline fdiinv & .00323317 & .00913568 \\
\hline hhi & .00126004 & .00043857 \\
\hline cap & $.19266421 * \star \star$ & $.24787347 * \star \star$ \\
\hline age & $.25833521 * \star \star$ & $.25423924 * \star \star$ \\
\hline size & $-.35612825 * \star \star$ & $-.03676492 *$ \\
\hline _cons & $5.321836 * \star \star$ & $5.0954851 * \star \star$ \\
\hline $\mathrm{N}$ & 8994 & 8994 \\
\hline r2 & .16158511 & .47943147 \\
\hline r2_a & .16055832 & .33840124 \\
\hline
\end{tabular}

legend: * $\mathrm{p}<0.05 ; * \star \mathrm{p}<0.01 ; * \star * \mathrm{p}<0.001$ 
Annex 12: The estimation result after incorporating the lagged value of the horizontal spillovers variable through labor mobility (lfdie)

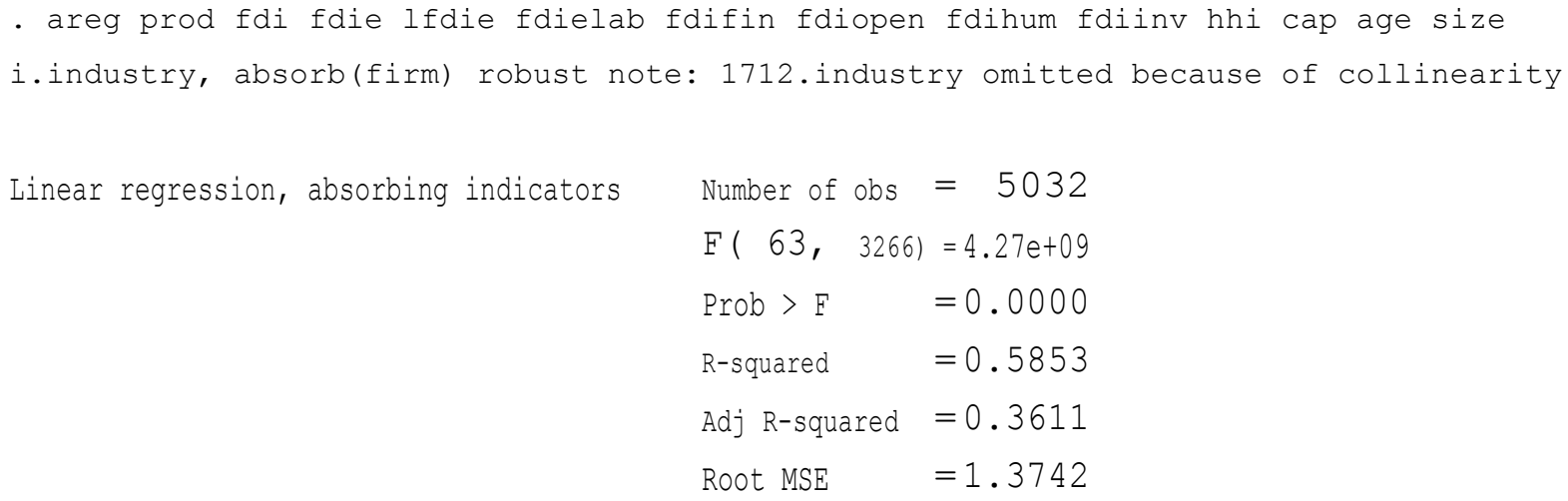

\begin{tabular}{l|l}
\hline $\operatorname{prod}$ & \\
Coef. Std. Err. & $\mathrm{t} \quad \mathrm{P}>|\mathrm{t}| \quad$ [95\% Conf. Interval]
\end{tabular}

\begin{tabular}{|c|c|c|c|}
\hline $\mathrm{fd}$ & & & \\
\hline fdie & -.0073655 .0033796 & -2.18 & $0.029-.0139919-.0007391$ \\
\hline & 899.0030151 & -1.16 & $0.247-.0094015 .0024217$ \\
\hline & -1.150 & -4 & $253-.6981685$ \\
\hline talit & .0715447 .026424 & 2.71 & 0.007 .01 \\
\hline . & .0726828 .0536253 & 1 . & $0.175-.032$ \\
\hline & .1694215 .0387 & 4 . & 0.000 .0934686 .2453745 \\
\hline & .00 & 0 . & 101 \\
\hline & .0 & 2 . & 0.007 \\
\hline & .261 & 19 & $0.000 \cdot 23$ \\
\hline & .1286 & & .014 \\
\hline & .0099198 .0249509 & 0 . & 0012.0588 \\
\hline
\end{tabular}


Annex 13: Number and Investment Capital of Approved Projects by Ownership since 1992/93 (Investment Capital in Millions of Birr)

\begin{tabular}{|c|c|c|c|c|c|c|c|c|}
\hline \multirow[b]{2}{*}{$\begin{array}{l}\text { Fiscal } \\
\text { Year }\end{array}$} & \multicolumn{2}{|c|}{ Domestic projects } & \multicolumn{2}{|c|}{ Foreign Projects } & \multicolumn{2}{|c|}{ Public Projects } & \multicolumn{2}{|c|}{ Total Projects } \\
\hline & $\begin{array}{l}\text { No. of } \\
\text { Project } \\
\text { s }\end{array}$ & $\begin{array}{l}\text { Investmet } \\
\text { Capital }\end{array}$ & $\begin{array}{l}\text { No. of } \\
\text { Projects }\end{array}$ & \begin{tabular}{|l|} 
Investme \\
nt \\
Capital
\end{tabular} & $\begin{array}{l}\text { No. of } \\
\text { Project } \\
\text { s }\end{array}$ & $\begin{array}{l}\text { Investme } \\
\text { nt Capital }\end{array}$ & $\begin{array}{l}\text { No. of } \\
\text { Projects }\end{array}$ & $\begin{array}{l}\text { Investme } \\
\text { nt Capital }\end{array}$ \\
\hline $1992 / 93$ & 542 & $3,750.0$ & 3 & 233 & 0 & 0.00 & 545 & $3,983.0$ \\
\hline 1993/94 & 521 & $2,926.0$ & 4 & 438 & 1 & 57.00 & 526 & $3,421.0$ \\
\hline $1994 / 95$ & 684 & $4,794.0$ & 7 & 505 & 2 & 39.00 & 693 & $5,338.0$ \\
\hline $1995 / 96$ & \begin{tabular}{|l|}
897 \\
\end{tabular} & $6,050.0$ & 10 & 434 & 1 & 6.00 & 908 & $6,490.0$ \\
\hline $1996 / 97$ & 752 & $4,447.0$ & 42 & 2,268 & 1 & 7.00 & 795 & $6,722.0$ \\
\hline $1997 / 98$ & 816 & $5,819.0$ & 81 & 4,106 & 1 & 14.00 & 898 & $9,939.0$ \\
\hline 1998/99 & 674 & $3,765.0$ & 30 & 1,380 & 9 & $4,915.00$ & 713 & $10,060.0$ \\
\hline 1999/00 & 561 & $6,740.0$ & 54 & 1,627 & 9 & $5,760.00$ & 624 & $14,127.0$ \\
\hline $2000 / 01$ & 635 & $5,675.7$ & 45 & 2,923 & 7 & 257.00 & 687 & $8,856.0$ \\
\hline 2001/02 & 756 & $6,117.3$ & 35 & 1,474 & 10 & $1,598.80$ & 801 & $9,190.2$ \\
\hline $2002 / 03$ & 1,127 & $9,362.9$ & 84 & 3,369 & 6 & 706.11 & 1,217 & $13,437.9$ \\
\hline $2003 / 04$ & \begin{tabular}{|l|}
1,862 \\
\end{tabular} & $12,177.7$ & 347 & 7,205 & 16 & $1,837.04$ & 2,225 & $21,220.0$ \\
\hline $2004 / 05$ & 2,240 & $19,571.7$ & 622 & 15,405 & 10 & $1,486.48$ & 2,872 & $36,463.3$ \\
\hline $2005 / 06$ & 5,100 & $41,841.1$ & 753 & 19,980 & 6 & $18,215.08$ & 5,859 & $80,036.3$ \\
\hline $2006 / 07$ & 5,322 & $46,630.1$ & 1,150 & 46,949 & 0 & 0.00 & 6,472 & $93,579.0$ \\
\hline $2007 / 08$ & 7,307 & $77,868.2$ & 1,651 & 92,249 & 3 & 261.56 & 8,961 & $170,378.5$ \\
\hline $2008 / 09$ & 7,184 & $83,630.2$ & 1,613 & 73,111 & 10 & $82,783.52$ & 8,807 & $239,524.8$ \\
\hline $2009 / 10$ & 5,080 & $40,852.2$ & 1,413 & 55,169 & 3 & 393.89 & 6,496 & $96,415.4$ \\
\hline $2010 / 11$ & 5,360 & 42,093 & 952 & 53,355 & 10 & 154,019 & $\begin{array}{l}6,322 \\
\end{array}$ & 249,469 \\
\hline 2011/12 & 5,042 & 59,316 & 604 & 83,975 & 3 & 2,877 & \begin{tabular}{|l|}
5,649 \\
\end{tabular} & 146,168 \\
\hline $2012 / 13$ & 6,273 & 34,823 & 722 & 49,485 & 16 & 27,763 & \begin{tabular}{|l|}
7,011 \\
\end{tabular} & 112,072 \\
\hline $\begin{array}{l}\text { Cumulat } \\
\text { ive }\end{array}$ & 58,735 & 518,250 & 10,220 & 515,641 & 124 & 302,997 & 69,079 & $1,336,890$ \\
\hline $\begin{array}{l}\text { Average } \\
\text { Annual }\end{array}$ & 2,797 & 24,679 & 487 & 24,554 & 6 & 14,428 & 3,289 & 63,661 \\
\hline
\end{tabular}

Source: Ethiopian Investment Agency 
Annex14: Numbers, Capital and Expected Job Opportunities (Inv.Capital in mill. of birr)

\begin{tabular}{|c|c|c|c|c|c|c|}
\hline & & 2010/11 & 2011/12 & $2012 / 13$ & \multicolumn{2}{|c|}{ Percentage change } \\
\hline & & $\overline{\mathbf{A}}$ & $\overline{\mathbf{B}}$ & C & C/A & $\mathrm{C} / \mathrm{B}$ \\
\hline \multirow{4}{*}{$\begin{array}{l}1 . \quad \text { Total } \\
\text { Investment }\end{array}$} & Number & 6,322 & 5,649 & 7,011 & 10.9 & 24.1 \\
\hline & Capital & 249,469 & 146,168 & 112,072 & -55.1 & -23.3 \\
\hline & $\begin{array}{l}\text { Permanent } \\
\text { Workers }\end{array}$ & 227,715 & 147,400 & 125,658 & -44.8 & -14.8 \\
\hline & $\begin{array}{l}\text { Temporary } \\
\text { Workers }\end{array}$ & 586,380 & 375,657 & 255,931 & -56.4 & -31.9 \\
\hline \multirow{4}{*}{ 2. Total Private } & Number & 6,312 & 5,646 & 6,995 & 10.8 & 23.9 \\
\hline & Capital & 95,450 & 143,291 & 84,309 & -11.7 & -41.2 \\
\hline & $\begin{array}{l}\text { Permanent } \\
\text { Workers }\end{array}$ & 212,470 & 147,286 & 125,488 & -40.9 & -14.8 \\
\hline & $\begin{array}{l}\text { Temporary } \\
\text { Workers }\end{array}$ & 412,117 & 375,504 & 255,401 & -38.0 & -32.0 \\
\hline \multirow{4}{*}{ 2.1. Domestic } & Number & 5,360 & 5,042 & 6,273 & 17.0 & 24.4 \\
\hline & Capital & 42,093 & 59,316 & 34,823 & -17.3 & -41.3 \\
\hline & $\begin{array}{l}\text { Permanent } \\
\text { Workers }\end{array}$ & 146,378 & 104,582 & 59,352 & -59.5 & -43.2 \\
\hline & $\begin{array}{l}\text { Temporary } \\
\text { Workers }\end{array}$ & 283,277 & 254,733 & 125,424 & -55.7 & -50.8 \\
\hline \multirow{4}{*}{ 2.2. Foreign } & Number & 952 & 604 & 722 & -24.2 & 19.5 \\
\hline & Capital & 53,357 & 83,975 & 49,485 & -7.3 & -41.1 \\
\hline & $\begin{array}{l}\text { Permanent } \\
\text { Workers }\end{array}$ & 66,092 & 42,704 & 66,136 & 0.1 & 54.9 \\
\hline & $\begin{array}{l}\text { Temporary } \\
\text { Workers }\end{array}$ & 128,840 & 120,771 & 129,977 & 0.9 & 7.6 \\
\hline \multirow{4}{*}{ 3. Public } & Number & 10 & 3 & 16 & 60.0 & - \\
\hline & Capital & 154,019 & 2,877 & 27,763 & -82.0 & - \\
\hline & $\begin{array}{l}\text { Permanent } \\
\text { Workers }\end{array}$ & 15,245 & 114 & 170 & -98.9 & 49.1 \\
\hline & $\begin{array}{l}\text { Temporary } \\
\text { Workers }\end{array}$ & 174,263 & 153 & 530 & -99.7 & 246.4 \\
\hline
\end{tabular}

Source: Ethiopian Investment Agency 


\section{Annex 15: Number and Capital of Investment Projects Approved by Sector}

(Capital in millions of birr)

\begin{tabular}{|c|c|c|c|c|c|c|}
\hline \multirow[b]{3}{*}{ Sectors } & \multicolumn{2}{|l|}{ 2011/12 } & \multicolumn{2}{|l|}{ 2012/13 } & \multicolumn{2}{|c|}{ Percentage share to total } \\
\hline & No. of & Investment & No. of & Investment & No. of & Investment \\
\hline & \begin{tabular}{|l|} 
Projects \\
\end{tabular} & Capital & Projects & \begin{tabular}{|l|} 
Capital \\
\end{tabular} & Projects & Capital \\
\hline Manufacturing & 1,211 & 45,482 & 1,005 & 35,399 & 14.3 & 31.6 \\
\hline $\begin{array}{l}\text { Agriculture, hunting } \\
\text { and forestry }\end{array}$ & 435 & 23,268 & 471 & 12,206 & 6.7 & 10.9 \\
\hline $\begin{array}{l}\text { Real estate, renting and } \\
\text { Business activities }\end{array}$ & 2,694 & 23,165 & 4,300 & 20,710 & 61.3 & 18.5 \\
\hline Hotel and restaurants & 271 & 12,322 & 208 & 5,297 & 3.0 & 4.7 \\
\hline Education & 57 & 465 & 44 & 845 & 0.6 & 0.8 \\
\hline Health and social work & 52 & 2,814 & 50 & 3,524 & 0.7 & 3.1 \\
\hline Construction & 747 & 29,794 & 725 & 5,486 & 10.3 & 4.9 \\
\hline $\begin{array}{l}\text { Wholesale, retail trade } \\
\text { and repair service }\end{array}$ & 22 & 322 & 37 & 177 & 0.5 & 0.2 \\
\hline $\begin{array}{l}\text { Transport, storage and } \\
\text { communication }\end{array}$ & 101 & 578 & 85 & 198 & 1.2 & 0.2 \\
\hline Fishing & 2 & 32 & - & - & 0.0 & 0.0 \\
\hline Mining and quarying & 9 & 159 & 14 & 154 & 0.2 & 0.1 \\
\hline $\begin{array}{l}\text { Electricity, gas, steam } \\
\text { and water supply }\end{array}$ & 2 & 7,129 & 16 & 27,707 & 0.2 & 24.7 \\
\hline $\begin{array}{l}\text { Other community, } \\
\text { social and personal } \\
\text { service activities }\end{array}$ & 46 & 639 & 56 & 369.2 & 0.8 & 0.3 \\
\hline Grand Total & 5,649 & 146,168 & 7,011 & 112,072 & 100.0 & 100.0 \\
\hline
\end{tabular}

\section{Source: Ethiopian Investment Agency}


Annex16: Number and Capital of Approved Projects by Region

(Capital in millions of Birr)

\begin{tabular}{|c|c|c|c|c|c|c|c|c|}
\hline & $2010 / 11$ & & 2011/12 & & $2012 / 13$ & & $\begin{array}{l}\text { Percent } \\
\text { share to }\end{array}$ & $\begin{array}{l}\text { ge } \\
\text { total }\end{array}$ \\
\hline Regions & $\begin{array}{l}\text { No. of } \\
\text { project } \\
\mathrm{s}\end{array}$ & $\begin{array}{l}\text { Investme } \\
\text { nt } \\
\text { Capital }\end{array}$ & $\begin{array}{l}\text { No. of } \\
\text { project } \\
\text { s }\end{array}$ & $\begin{array}{l}\text { Invest } \\
\text { ment } \\
\text { Capital }\end{array}$ & $\begin{array}{l}\text { No. of } \\
\text { of } \\
\text { project } \\
\text { S }\end{array}$ & $\begin{array}{l}\text { Investm } \\
\text { ent } \\
\text { Capital }\end{array}$ & $\begin{array}{l}\text { No. of } \\
\text { of } \\
\text { project } \\
\text { s }\end{array}$ & $\begin{array}{l}\text { Inve } \\
\text { stme } \\
\text { nt } \\
\text { Capi } \\
\text { tal }\end{array}$ \\
\hline Tigray & 349 & 11,112 & 7 & 130 & 17 & 580 & 0.2 & 0.5 \\
\hline Afar & 26 & 399 & 50 & 190 & 89 & 1,174 & 1.3 & 1.0 \\
\hline Amhara & 722 & 32,753 & 612 & 38,642 & 829 & 10,469 & 11.8 & 9.3 \\
\hline Oromia & 1,386 & 32,219 & 510 & 25,714 & 846 & 49,111 & 12.1 & 43.8 \\
\hline Somali & 127 & 2,738 & 50 & 1,001 & 4 & 24 & 0.1 & 0.0 \\
\hline $\begin{array}{l}\text { Benishang } \\
\text { ul-Gumuz }\end{array}$ & 56 & 81,611 & 50 & 354 & 33 & 114 & 0.5 & 0.1 \\
\hline SNNPR & 160 & 49,751 & 49 & 2,845 & 125 & 3,140 & 1.8 & 2.8 \\
\hline Gambella & 14 & 3,920 & 11 & 6,265 & 4 & 163 & 0.1 & 0.1 \\
\hline Harari & 48 & 276 & 4 & 974 & 1 & 10 & 0.0 & 0.0 \\
\hline $\begin{array}{l}\text { Addis } \\
\text { Ababa }\end{array}$ & 3,221 & 30,627 & 4,170 & 62,264 & 4,890 & 36,160 & 69.7 & 32.3 \\
\hline Dire Dawa & 207 & 2,995 & 134 & 660 & 170 & 1,730 & 2.4 & 1.5 \\
\hline $\begin{array}{l}\text { Multiregio } \\
\text { nal } \\
\text { Projects }\end{array}$ & 6 & 1,067 & 2 & 7,129 & 3 & 9,397 & 0.0 & 8.4 \\
\hline $\begin{array}{l}\text { Grand } \\
\text { Total }\end{array}$ & 6,322 & 249,469 & $5,649.0$ & 146,168 & 7,011 & 112,072 & 100.0 & $\begin{array}{l}100 . \\
0\end{array}$ \\
\hline
\end{tabular}

Source: Ethiopian Investment Agency 
Annex 17: Total employment by Major Industrial Groups

\begin{tabular}{|c|c|c|c|c|}
\hline $\begin{array}{l}\text { Division of ISIC } \\
\text { Rev.3 }\end{array}$ & MajorIndustrial groups & 2003 & 2005 & 2010 \\
\hline 15 & Food and Beverge & 22865 & 26717 & 50998 \\
\hline 16 & Tobacco Products & 936 & 692 & 984 \\
\hline 17 & Textile & 20399 & 19381 & 20163 \\
\hline 18 & $\begin{array}{l}\text { Wearing Apparel except } \\
\text { Fur apparel }\end{array}$ & 3576 & 3607 & 9448 \\
\hline 19 & $\begin{array}{l}\text { Tanning and Dressing of } \\
\text { Leather }\end{array}$ & 6553 & 7545 & 9050 \\
\hline 20 & $\begin{array}{l}\text { Wood and products of } \\
\text { wood }\end{array}$ & 1015 & 1134 & 3286 \\
\hline $21-22$ & $\begin{array}{l}\text { Paper, Paper products and } \\
\text { printing }\end{array}$ & 5884 & 7476 & 8449 \\
\hline 24 & $\begin{array}{l}\text { Chemical and chemical } \\
\text { Products }\end{array}$ & 4266 & 4992 & 9596 \\
\hline 25 & $\begin{array}{l}\text { Rubber and Plastic } \\
\text { Products }\end{array}$ & 4207 & 6529 & 12721 \\
\hline 26 & $\begin{array}{l}\text { Othernon metallic mineral } \\
\text { products }\end{array}$ & 6114 & 7978 & 17763 \\
\hline 27 & Basic Iron and Steal & 1653 & 1985 & 1946 \\
\hline 28 & Fabricated Metal products & 2503 & 1569 & 10364 \\
\hline 29 & Machinery and equipment & 240 & 184 & 403 \\
\hline 34 & $\begin{array}{l}\text { Vechiles,Trailers and } \\
\text { Semi- Trailers }\end{array}$ & 921 & 1459 & 260 \\
\hline 36 & Furniture & 3927 & 4923 & 5105 \\
\hline & Total & 85059 & 96171 & 160536 \\
\hline
\end{tabular}

Source: Central Statistics Authority 
Annex 18: Trends in Value Added Contribution by Major Industrial Group

\begin{tabular}{|c|c|c|c|c|}
\hline $\begin{array}{l}\text { Division of ISIC } \\
\text { Rev.3 }\end{array}$ & MajorIndustrial groups & 2001 & 2005 & 2010 \\
\hline 15 & Food and Beverge & 37.15 & 40.3 & 47.2 \\
\hline 16 & Tobacco Products & 4.92 & 3.7 & 2.0 \\
\hline 17 & Textile & 4.87 & 3.4 & 2.2 \\
\hline 18 & $\begin{array}{l}\text { Wearing Apparel except } \\
\text { Fur apparel }\end{array}$ & 0.86 & 0.6 & 1.1 \\
\hline 19 & $\begin{array}{l}\text { Tanning and Dressing of } \\
\text { Leather }\end{array}$ & 2.89 & 4.4 & 7.6 \\
\hline 20 & $\begin{array}{l}\text { Wood and products of } \\
\text { wood }\end{array}$ & 0.41 & 0.8 & 0.9 \\
\hline $21-22$ & $\begin{array}{l}\text { Paper, Paper products and } \\
\text { printing }\end{array}$ & 5.68 & 5.3 & 5.6 \\
\hline 24 & $\begin{array}{l}\text { Chemical and chemical } \\
\text { Products }\end{array}$ & 8.89 & 4.8 & 10.5 \\
\hline 25 & $\begin{array}{l}\text { Rubber and Plastic } \\
\text { Products }\end{array}$ & 5.9 & 8.9 & 5.9 \\
\hline 26 & $\begin{array}{l}\text { Othernon metallic mineral } \\
\text { products }\end{array}$ & 16.41 & 15.7 & 16.4 \\
\hline 27 & Basic Iron and Steal & 3.39 & 3.9 & 4.2 \\
\hline 28 & Fabricated Metal products & 4.59 & 3.0 & -6.7 \\
\hline 29 & Machinery and equipment & 0.08 & 0.3 & 0.8 \\
\hline 34 & $\begin{array}{l}\text { Vechiles,Trailers and } \\
\text { Semi- Trailers }\end{array}$ & 1.57 & 2.4 & 0.6 \\
\hline 36 & Furniture & 2.39 & 2.4 & 2.3 \\
\hline & Total & 100.00 & 100.00 & 100.00 \\
\hline
\end{tabular}

Source: Compiled from CSA (2011 and 2012) report 
Annex 19: ISIC codes for Manufacturing Industries

\begin{tabular}{|c|c|}
\hline ISIC & Description \\
\hline 1511 & Production, Processing and preserving of meat, fruit and vegetable \\
\hline 1514 & Manufacture of edible oil \\
\hline 1520 & Manufacture of dairy products \\
\hline 1531 & Manufacture of flour \\
\hline 1533 & Manufacture of animal feed \\
\hline 1541 & Manufacture of Bakery \\
\hline 1542 & Manufacture of Sugar \\
\hline 1544 & Manufacture of Pasta and Macaroni \\
\hline 1549 & Manufacture of food products NEC \\
\hline 1551 & Distilling, rectifying and blending of spirit \\
\hline 1552 & Manufacture of Wine \\
\hline 1553 & Manufacture of malt liquors and malt \\
\hline 1554 & Manufacture of soft drinks \\
\hline 1600 & Manufacture of tobacco \\
\hline 1710 & Spinning, weaving and finishing \\
\hline 1711 & Preparation and spinning of textile fibers \\
\hline 1712 & Finishing of textiles \\
\hline 1720 & Manufacture of made up textile articles, except apparel \\
\hline 1723 & Manufacture of cordage rope and twine \\
\hline 1730 & Manufacture of knitted and crocheted fabrics and articles \\
\hline 1810 & Manufacture of wearing apparel except fur \\
\hline 1910 & Tanning and dressing of leather \\
\hline 1920 & Manufacture of foot ware \\
\hline 2000 & Manufacture of wood and wood products \\
\hline 2100 & Manufacture of paper and paper products \\
\hline 2200 & publishing and printing services \\
\hline 2411 & Manufacture of basic chemicals except fertilizers \\
\hline
\end{tabular}




\begin{tabular}{|c|c|}
\hline 2421 & Manufacture of pesticides and other chemical products \\
\hline 2422 & Manufacture of paints varnishes \\
\hline 2423 & Manufacture of Pharmaceuticals, medicinal chemicals and botanical products \\
\hline 2424 & Manufacture of soap detergents, perfumes \\
\hline 2429 & Manufacture of chemical products NEC \\
\hline 2510 & Manufacture of Rubber \\
\hline 2520 & Manufacture of plastics \\
\hline 2610 & Manufacture of glass and glass products \\
\hline 2693 & Manufacture of structural clay products \\
\hline 2694 & Manufacture of cement, lime and plaster \\
\hline 2695 & Manufacture of articles of concrete and cement \\
\hline 2699 & Manufacture of non metallic NEC \\
\hline 2710 & Manufacture of basic iron and steel \\
\hline 2811 & Manufacture of structural metal products \\
\hline 2892 & Manufacture of cutlery hand tools \\
\hline 2893 & Manufacture of other fabricated metal products \\
\hline 2899 & Manufacture of pumps, compressors, valves and taps \\
\hline 2914 & Manufacture of ovens \\
\hline 2924 & Manufacture of machinery for mining, quarrying and construction \\
\hline 2925 & Manufacture of other general purpose machinery \\
\hline 3130 & Manufacture of insulated wire and cable \\
\hline 3140 & Manufacture of accumulators, primary sells and primary batteries \\
\hline 3420 & Manufacture of bodies for motor vehicles \\
\hline 3430 & Manufacture of parts and accessories for motor vehicles and their engines \\
\hline 3610 & Manufacture of furniture \\
\hline
\end{tabular}

Source: International Standard Industrial Classification (ISIC Revision 4.1)

\footnotetext{
ABC Research Alert, Vol 3, No 3 (2015)

ISSN 2413-5224
} 